\title{
Evaluation of salt tolerance in Eruca sativa accessions based on morpho-physiological traits
}

\author{
Sadia Afsar ${ }^{1}$, Gulnaz Bibi $^{1}$, Raza Ahmad ${ }^{1}$, Muhammad Bilal $^{2}$, Tatheer Alam Naqvi ${ }^{1}$, Ayesha Baig $^{1}$, Mohammad \\ Maroof Shah $^{1}$, Bangquan Huang ${ }^{3}$, Jamshaid Hussain ${ }^{\text {Corresp. } 1}$ \\ 1 Department of Biotechnology, COMSATS University Islamabad, Abbottabad Campus, Abbottabad, Pakistan \\ 2 Department of Environmental Sciences, COMSATS University Islamabad, Abbottabad Campus, Abbottabad, Pakistan \\ 3 State Key Laboratory of Biocatalysis and Enzyme Engineering, College of Life Science, Hubei University, Wuhan, China \\ Corresponding Author: Jamshaid Hussain \\ Email address: jamshaidhussain@cuiatd.edu.pk
}

Background. Salinity is one of the most lethal abiotic stresses which affect multiple aspects of plant physiology. Natural variations in plant germplasm are a great resource that could be exploited for improvement in salt tolerance. Eruca sativa (E. sativa) exhibits tolerance to abiotic stresses. However, thorough evaluation of its salt stress tolerance and screening for traits that could be reliably applied for salt tolerance needs to be studied. The current study was designed to characterize $25 \mathrm{E}$. sativa accessions, originating from diverse geographical regions of Pakistan, for the salt stress tolerance. Methods. Salt stress (150 mM NaCl) was applied for two weeks to the plants at four leaf stage in hydroponics. Data of the following morpho-physiological traits were collected from control and treated plants of all the accessions: Root length (RL), shoot length (SL), plant height $(\mathrm{PH})$, leaf number (LN), leaf area (LA), fresh weight (FW), dry weight (DW), chlorophyll content (SPAD), electrolyte leakage (EL), relative water content (RWC), gas exchange parameters and mineral ion content. Salt tolerance was determined based on membership function value (MFV) of the tested traits. Results. Compared with control, the saltstressed group had significantly reduced mean $\mathrm{SL}, \mathrm{RL}, \mathrm{PH}, \mathrm{LN}, \mathrm{LA}, \mathrm{FW}, \mathrm{DW}$, and SPAD. $\mathrm{NaCl}$ treatment triggered a slight increase in EL in few accessions. Mean RWC of control and treated groups were not significantly different although few accessions exhibited variation in this trait. Salt stress caused a significant reduction in photosynthesis rate (PR), transpiration rate (TR), and stomatal conductance (SC) but intercellular $\mathrm{CO}_{2}(\mathrm{Ci})$ was not significantly different between control and treated groups. Compared with control, the saltstressed plants accumulated significantly higher $\mathrm{Na}^{+}, \mathrm{K}^{+}$, and $\mathrm{Ca}^{2+}$ while significantly lower $\mathrm{Mg}^{2+} . \mathrm{K}^{+} / \mathrm{Na}^{+}$ratio was significantly decreased in salt-stressed plants compared with control. Importantly, significant inter-accession variations were found for all the tested traits. The principal component analysis identified SL, RL, PH, LN, LA, FW, DW, and PR as Peerj reviewing PDF |(2020:05:48976:1:1:NEW 10 Jül 2020) 
the most significant traits for resolving inter-accession variability. Based on MFV of the tested traits, accessions were categorized into five standard groups. Among 25 accessions, 1 accession was ranked as highly tolerant, 4 as tolerant while 15 accessions were ranked as moderately tolerant. Of the remaining 5 accessions, 4 were ranked as sensitive while 1 accession as highly sensitive. Conclusion. $E$. sativa accessions were found to exhibit significant genetic diversity in all the tested traits. A few most significant traits for dissecting the genetic variability were identified that could be used for future large-scale germplasm screening in E. sativa. Salt tolerant accessions could be a good resource for future breeding programs aiming to improve salt stress tolerance. 
1 Evaluation of salt tolerance in Eruca sativa

2 accessions based on morpho-physiological traits

3

4

5
6

Sadia Afsar ${ }^{1}$, Gulnaz Bibi ${ }^{1}$, Raza Ahmad ${ }^{1}$, Muhammad Bilal ${ }^{2}$, Tatheer Alam Naqvi ${ }^{1}$, Ayesha Baig ${ }^{1}$, Mohammad Maroof Shah ${ }^{1}$, Bangquan Huang ${ }^{3}$ and Jamshaid Hussain ${ }^{1 *}$

${ }^{1}$ Department of Biotechnology, COMSATS University Islamabad, Abbottabad Campus, 22060, Abbottabad, Pakistan

${ }^{2}$ Department of Environmental Sciences, COMSATS University Islamabad, Abbottabad Campus, 22060, Abbottabad, Pakistan

${ }^{3}$ State Key Laboratory of Biocatalysis and Enzyme Engineering, College of Life Science, Hubei University, Wuhan 430062, China

Corresponding Author:

Jamshaid Hussain ${ }^{1}$

Department of Biotechnology, COMSATS University Islamabad, Abbottabad Campus, 22060, Abbottabad, Pakistan

Email address: jamshaidhussain@cuiatd.edu.pk

\section{Abstract}

Background. Salinity is one of the most lethal abiotic stresses which affect multiple aspects of plant physiology. Natural variations in plant germplasm are a great resource that could be exploited for improvement in salt tolerance. Eruca sativa (E. sativa) exhibits tolerance to abiotic stresses. However, thorough evaluation of its salt stress tolerance and screening for traits that could be reliably applied for salt tolerance needs to be studied. The current study was designed to characterize 25 E. sativa accessions, originating from diverse geographical regions of Pakistan, for the salt stress tolerance.

Methods. Salt stress $(150 \mathrm{mM} \mathrm{NaCl})$ was applied for two weeks to the plants at four leaf stage in hydroponics. Data of the following morpho-physiological traits were collected from control and treated plants of all the accessions: Root length (RL), shoot length (SL), plant height (PH), leaf number (LN), leaf area (LA), fresh weight (FW), dry weight (DW), chlorophyll content (SPAD), electrolyte leakage (EL), relative water content (RWC), gas exchange parameters and mineral ion content. Salt tolerance was determined based on membership function value (MFV) of the tested traits.

Results. Compared with control, the salt-stressed group had significantly reduced mean SL, RL, $\mathrm{PH}, \mathrm{LN}, \mathrm{LA}, \mathrm{FW}, \mathrm{DW}$, and SPAD. $\mathrm{NaCl}$ treatment triggered a slight increase in EL in few accessions. Mean RWC of control and treated groups were not significantly different although few accessions exhibited variation in this trait. Salt stress caused a significant reduction in photosynthesis rate (PR), transpiration rate (TR), and stomatal conductance (SC) but intercellular $\mathrm{CO}_{2}(\mathrm{Ci})$ was not significantly different between control and treated groups. Compared with 
40 control, the salt-stressed plants accumulated significantly higher $\mathrm{Na}^{+}, \mathrm{K}^{+}$, and $\mathrm{Ca}^{2+}$ while

41 significantly lower $\mathrm{Mg}^{2+} . \mathrm{K}^{+} / \mathrm{Na}^{+}$ratio was significantly decreased in salt-stressed plants

42 compared with control. Importantly, significant inter-accession variations were found for all the

43 tested traits. The principal component analysis identified SL, RL, PH, LN, LA, FW, DW, and PR

44 as the most significant traits for resolving inter-accession variability. Based on MFV of the tested

45 traits, accessions were categorized into five standard groups. Among 25 accessions, 1 accession

46 was ranked as highly tolerant, 4 as tolerant while 15 accessions were ranked as moderately

47 tolerant. Of the remaining 5 accessions, 4 were ranked as sensitive while 1 accession as highly

48 sensitive.

49 Conclusion. E. sativa accessions were found to exhibit significant genetic diversity in all the

50

51 tested traits. A few most significant traits for dissecting the genetic variability were identified that could be used for future large-scale germplasm screening in E. sativa. Salt tolerant

52 accessions could be a good resource for future breeding programs aiming to improve salt stress tolerance.

54

55

56

57

58

59

60

61

62

63

64

65

66

67

68

69

70

71

72

73

74

75

76

77

78

\section{Introduction}

Salt stress is one of the major abiotic stresses affecting the productivity of cultivated soils. The salt-affected areas are increasing, and the irrigated soils are more prone to damage by salinity. Presently about 45 million hectares of irrigated land is affected by salinity. Furthermore, it is estimated that about half of the world's arable land could become salinized by 2050 ( $\mathrm{Li}$ et al., 2014; Machado \& Serralheiro, 2017). For addressing challenges to the global food security, genetic engineering to create salt tolerant species is considered as a promising strategy (Bhardwaj et al., 2010; Shokri-Gharelo \& Noparvar, 2018).

Salt stress is one of the most common abiotic stresses which affect multiple aspects of plant physiology (Munns \& Tester, 2008; Fageria et al., 2012). It disrupts nutrient ion balance, decreases stomatal conductance, and negatively affects the photosynthetic activity. Excessive salt accumulation severely impairs the membrane integrity, water relations, and pigment content of plants (Acosta-Motos et al., 2017; Munns \& Tester, 2008). The plants undergo morphological alterations which include a reduction in root and shoot length, plant height, and leaves size and number (Munns \& Tester, 2008). As most of the important crops are glycophytes hence their growth is seriously hindered by salt stress (Yang \& Guo, 2018).

Natural variations in plant germplasm are a great resource that could be exploited for improvement in salt tolerance without affecting valuable agronomic traits. Genetic variations could be exploited by plant biologists to identify the physiological mechanisms, sets of genes and proteins involved in stress tolerance. Subsequently, these genes can be subsequently incorporated in suitable plant species to yield salt stress tolerant varieties (Gupta \& Huang 2014; Ismail \& Horie, 2017; Singh et al., 2018). Moreover, a reliable and extensive phenotypic evaluation of germplasm is important for the identification of tolerance-associated traits (Ismail \& Horie, 2017). 
79 Several factors are responsible for the lack of success in developing salt tolerant genotypes.

80 These include low efficiency of morphological, biochemical and physiological parameters being 81 used as screening criteria, limited availability of genetic diversity for breeding programs, and the 82 lack of efficient evaluation methods for identifying salt tolerant genotypes through multivariable 83 screening criteria (Zeng et al., 2002; Oyiga et al., 2016).

84 Eruca sativa (also known as rocket or arugula, and locally as taramira) is a diploid herbaceous 85 plant from Brassicaceae family. It is an important industrial crop that can grow in poor fertility 86 lands and diverse climatic conditions. E. sativa exhibits tolerance to abiotic stresses like salt, 87 drought, and temperature stress (Ashraf, 1994; Shannon \& Grieve, 1999; Garg \& Sharma, 88 2014). The seed oil of E. sativa possesses antimicrobial, anti-cancerous and antioxidant 89 properties (Khoobchandani et al., 2010; Azarenko et al., 2014). Furthermore, due to high erucic 90 acid content, E. sativa is considered as a potential source for industrial oil (Pignone \& GomezCampo, 2011). E. sativa exhibits significant genetic diversity and a broader market range. There is huge potential for germplasm improvement however limited work on this crop has been carried out so far (Slater, 2013). The genetic variability in E. sativa is a valuable resource that could be exploited in order to screen for high salt tolerance. However, a thorough evaluation of its salt stress tolerance or screening for traits that could be reliably applied for salt tolerance needs to be carried out.

Keeping in mind the above mentioned research gaps, major objectives of the current research were as follows: (1) to understand the effect of salt stress on growth and development of $E$. sativa accessions, (2) to determine the extent of variability in salinity tolerance among $E$. sativa accessions, (3) to identify morpho-physiological traits with a maximum contribution towards variability, and (4) to identify the salt tolerant and salt sensitive accessions for further studies and future breeding programs.

\section{Materials \& Methods}

\section{Plant material, growth conditions, and salt stress treatment}

Twenty five E. sativa accessions were used in this study. The seeds of these accessions were kindly provided by Bio-Resources Conservation Institute, National Agricultural Research Centre, Islamabad, Pakistan. The list of accessions along with other details is given in Table S1. The seeds were surface sterilized and sown in a thick moist sheet of foam which was then placed in 72-cell seed starter trays in a growth chamber under controlled conditions of $16 \mathrm{~h} / 8 \mathrm{~h}$ day night $\left(350 \mu \mathrm{mol} / \mathrm{m}^{2} / \mathrm{s}^{2}\right)$ at $23^{\circ} \mathrm{C}$ and $60 \%$ relative humidity. After one week of growth, uniform sized seedlings were transferred the Hoagland-type solution (Hoagland \& Arnon, 1938) in 4-liter plastic containers. The set up was placed in a growth chamber under controlled conditions (as mentioned above). The solution was changed every 2-3 days. The experiment was carried out in a completely randomized design (CRD). Plants were divided into two groups; one as control (0 $\mathrm{mM} \mathrm{NaCl})$ and other as treated $(150 \mathrm{mM} \mathrm{NaCl})$. At the four-leaf stage, the salt stress was applied for two weeks. Before the determination of gas exchange parameters plants were kept in full sunlight for two hours (9.00 a.m. to 11.00 a.m.). 
119 Determination of plant growth and development traits

120 Data from control and treated plants was collected after 14 days of growth. Morphological traits 121 i.e. shoot length (SL), root length (RL), plant height (PH), and leaf attributes i.e leaf number

122 (LN) and leaf area (LA) were recorded. The experiment was performed in six replicates for each 123 parameter. SL, RL, and PH were measured from digital images by using image analysis software 124 Digimizer. The leaf area was manually measured using a grid paper. Fresh weight of control and

125

126

127

128

129

130

131

132

133

134

135

136

137

138

139

140

141

142

143

144

145

146

147

148

149

150

151

152

153

154

155

156 treated plants was determined immediately after harvesting by using a digital lab scale. For determination of dry weight, whole plants (root + shoot) were dried in an incubator at $75{ }^{\circ} \mathrm{C}$ for $72 \mathrm{~h}$, and then weight was determined by using a digital lab scale. Plant biomass assay was carried out in three replicates.

\section{Electrolyte leakage}

Electrolyte leakage (EL) was determined following the previously described method (Yildirim et al., 2009). Briefly, ten equal size leaf discs (10 mm diameter) from fully expanded leaves of control and treated plants were prepared and washed with deionized water to remove electrolytes adhered to the surface. These were then incubated at $10^{\circ} \mathrm{C}$ for $24 \mathrm{~h}$ in glass tubes filled with 10 $\mathrm{ml}$ of deionized water and the 1st electrical conductivity reading (EC1) was recorded. The tubes were heated at $95{ }^{\circ} \mathrm{C}$ in a water bath for $20 \mathrm{~min}$ to release all the electrolytes. After cooling at room temperature, final electrical conductivity reading (EC2) was recorded. The EC readings were determined by using a portable conductometer (HI-98129 Pocket EC/TDS and pH Tester). The experiment was performed in three replicates. Following equation was used for the calculation of EL:

$$
E L=(E C 1 / E C 2) \times 100
$$

\section{Determination of chlorophyll content}

Relative chlorophyll content was measured by using Chlorophyll Meter (CCM-200plus, OptiSciences). Fully expanded $4^{\text {th }}$ leaf from all the plants (control and treated) was selected for the reading. The data are presented in the form of chlorophyll content Index (CCI). All the measurements were recorded in six replicates.

\section{Relative water content}

Relative Water Content (RWC) was determined from the data of fresh, dry, and turgid weight of control and treated plants, as described previously (Loutfy et al., 2012). The experiment was performed in three replicates. RWC was calculated by using the formula:

$$
\operatorname{RWC}(\%)=\left\lfloor\frac{\mathrm{FW}-\mathrm{DW}}{\mathrm{TW}-\mathrm{DW}}\right\rfloor \times 100
$$

where FW stands for fresh weight, TW for turgid weight, and DW for dry weight.

\section{Mineral ion content}

For the determination of mineral ions, $100 \mathrm{mg}$ of dried whole plant samples were placed in a furnace for $5 \mathrm{hrs}$ at $520^{\circ} \mathrm{C}$ for ash formation. It was then mixed with the nitric acid-perchloric acid mixture $(5: 1)$ and the final volume was raised to $15 \mathrm{ml}$ with distilled water. The filtrate was used to determine the concentrations of $\mathrm{Na}^{+}, \mathrm{K}^{+}, \mathrm{Ca}^{2+}$, and $\mathrm{Mg}^{2+}$ by atomic absorption 
157 spectrometry. For standard curves, different concentrations of $\mathrm{Na}^{+}, \mathrm{K}^{+}, \mathrm{Ca}^{2+}$, and $\mathrm{Mg}^{2+} \mathrm{Were}^{2}$

158

159

160

161

162

163

164

165

166

167

168

169

170

171

172

173

174

175

176

177

178

179

180

181

182

183

184

185

186

187

188

189

190

191

192

193

prepared by diluting stock solutions of $\mathrm{CaSO}_{4}, \mathrm{KCl}, \mathrm{NaCl}$, and $\mathrm{MgSO}_{4}$. The standard curve was used to determine the content of each element and the values were expressed in $\mathrm{mg} / \mathrm{g} \mathrm{DW}$. The experiment was performed in three replicates.

\section{Leaf gas exchange parameters}

The photosynthesis rate (PR), intercellular $\mathrm{CO}_{2}$ concentration $(\mathrm{Ci})$, transpiration rate (TR), and stomatal conductance (SC) were measured with a portable gas exchange system iFL (ADC BioScientific Ltd., Hoddesdon, UK). All the measurements were conducted on a sunny day with full light intensity (11.00 a.m. to 4.00 p.m.). Young fully expanded leaves ( 3 rd \& 4th) were used in situ for recording the above mentioned gas exchange parameters. All the measurements were recorded in four replicates. The following conditions were applied for the assay: Leaf surface diameter $6 \mathrm{~cm}$, ambient atmospheric $\mathrm{CO}_{2}$ concentration (Cref) $352 \mu \mathrm{mol} \mathrm{mol}^{-1}$, PAR (Qleaf): $1200 \mu \mathrm{mol} / \mathrm{m}^{2} \mathrm{~s}$ and wide- range of chamber water vapor pressure 4.4 to $6.6 \mathrm{mbar}$. Three plants from each accession and treatment were analyzed for leaf gas exchange parameters.

\section{Salt tolerance evaluation}

The data of all morpho-physiological parameters (control and treatment) for each accession was converted to the salt-tolerance index (STI) which is the ratio of the value for the NaCl-treated plant/value for the control. For the categorization of E. sativa accessions according to their salt tolerance, membership function value (MFV) was applied as previously described (Chen et al., 2012). The MFV was calculated according to the following formula:

$$
X_{p}=\frac{X-X_{\text {min }}}{X_{\text {max }}-X_{\text {min }}} \times 100 \%
$$

For the traits inversely related to salt tolerance (e.g EL), following formula for MFV calculation was used:

$$
X_{p}=1-\frac{\left(X-X_{\min }\right)}{\left(X_{\max }-X_{\min }\right)} \times 100 \%
$$

Where Xp is the MFV value of the salt stress parameter "P" in a specific accession, $\mathrm{X}$ is the actual value of salt tolerance parameter while $X_{\min }$ and $X_{\max }$ represent the minimum and maximum MFV values, respectively, for that parameter in all accessions. A single MFV value $\left(X_{c}\right)$ was obtained for each accession by taking the mean of MFV values of all tested morphophysiological traits. E. sativa accessions were divided into 5 standard groups according to the average MFV value (Xa) and S.D. The accession was considered as highly tolerant if $\mathrm{Xc} \geq \mathrm{Xa}+$ 1.64 S.D., tolerant if the $\mathrm{Xa}+1 \mathrm{SD} \leq \mathrm{Xc}<\mathrm{Xa}+1.64$ S.D., moderately tolerant if $\mathrm{Xa}-1$ S.D. $\leq \mathrm{Xc}<\mathrm{Xa}+1$ S.D., sensitive if $\mathrm{Xa}-1.64$ S.D. $\leq \mathrm{Xc}<\mathrm{Xa}-1$ S.D., and highly sensitive if $\mathrm{Xc}<$ Xa - 1.64 S.D.

\section{Statistical analysis}

Differences among accessions and treatments were considered statistically significant at $\mathrm{p}<0.05$

by Duncan's multiple-range test performed using IBM SPSS Statistics for Windows, V.20 (IBM Corp). Principal component analysis (PCA), cluster analysis, and correlation matrix analyses 
194

195

196

197

198

199

200

201

202

203

204

205

206

207

208

209

210

211

212

213

214

215

216

217

218

219

220

221

222

223

224

225

226

227

228

229

230

231

232

233

were performed on MFV values of studied salt tolerance traits using STATISTICA Statsoft (version 10).

\section{Results}

\section{Morphological traits leaf attributes}

Shoot length (SL) was significantly reduced in the salt-stressed plants compared with the control $(p<0.05)$. The mean SL values for the control and treatments groups were $2.30 \pm 0.56$ and $1.10 \pm 0.48$ inches, respectively (Table 1). To determine the salt stress response of accessions based on shoot growth, SL of each accession was expressed as stress index, as described in the material and methods section. Accessions showing the higher stress index were considered more salt tolerant and vice versa. SL stress index of accessions varied from 16.74 to 88.96 . Es- 1 and Es-15 exhibited the highest and the lowest SL stress index, respectively (Fig. 1A). Salt stress significantly inhibited root length (RL) as compared to control $(\mathrm{p}<0.05)$. Mean $R L$ values in control and treated groups were $2.17 \pm 0.42$ and $0.98 \pm 0.43$ inches, respectively (Table 1). RL stress index ranged from 15.88-73.47. The highest RL stress index was exhibited by Es12 while the lowest by Es-18 (Fig. 1B).

Plant height $(\mathrm{PH})$ was also significantly reduced in salt-stressed plants compared with control $(\mathrm{p}<0.05)$. Mean PH values for control and treated groups were $4.43 \pm 0.77$ and $2.18 \pm 0.76$ inches, respectively (Table 1). PH stress index varied from 19.80 to 73.98; accessions Es-1 and Es-18 showed the highest and the lowest stress index, respectively (Fig. 1C).

Leaf number (LN) and leaf area (LA) were also significantly reduced in salt-stressed plants compared to control $(\mathrm{p}<0.05)$. Mean $\mathrm{LN}$ for control and treatment groups were $4.22 \pm 0.78$ and $2.43 \pm 0.82$, respectively (Table 1). LN stress index varied from 28 to 94.12 ; Es-19 exhibited the highest stress index while Es-17 the lowest (Fig. 1D). Mean LA was also significantly less in the treated group compared with control $(\mathrm{p}<0.05)$ (Table 1). Mean LA for control and treatment groups was $0.07 \pm 0.025$ and $0.03 \pm 0.016 \mathrm{inch}^{2}$, respectively (Table 1). LA stress index varied from 7.6 to100; Es-25 and Es-3 showed the highest and the lowest stress index, respectively (Fig. 1E). To summarize, these data show that salt stress significantly inhibited morphological traits in all the accessions. Moreover, the extent of inhibition of these traits, by salt stress, was variable in E. sativa accessions.

\section{Plant biomass}

Salt stress significantly reduced the FW and DW of $E$. sativa plants ( $<0.05)$. Mean FW values in control and treatment groups were $241 \pm 164 \mathrm{mg}$ and $96 \pm 66 \mathrm{mg}$, respectively (Table 2). FW stress index ranged from 10.2 to 83.92 (Fig. 2A). Cultivar Es-9 showed the highest FW stress index while Es-3 the lowest (Fig. 2). Mean DW values for control and treated groups were $10.6 \pm 6.9$ and $6.29 \pm 3.9 \mathrm{mg}$, respectively (Table 2). DW stress index varied from 24.65 to 87.42 . Es-12 and Es-3 exhibited the highest and the lowest DW stress index, respectively (Fig. 2B).

\section{Relative water content, electrolyte leakage, and chlorophyll content}


234 Mean relative water content (RWC) values of control and treatment groups were not

235 significantly different, being $92.11 \pm 7 \%$ and $92.83 \pm 2.6 \%$, respectively ( $>0.05$ ) (Table 2 ).

236 However, moderate but significant variations in RWC were observed between control and its 237 treated counterpart for few accessions $(\mathrm{p}<0.05)$ (Table 2). RWC, in the control group, varied 238 from 71.6 to $98.8 \%$ while in the treated group from 88.6 to $96.3 \%$. Among the control group, Es2392 and Es-6 showed the lowest and the highest RWC, respectively. In the treated group Es-18 240 showed the lowest while Es-4 showed the highest RWC (Table 2).

241 The electrolyte leakage (EL) data is presented in fig. 3 as the ratio of treated to control for each 242 accession. A higher ratio showed an increased EL due to salt stress. Moderate but statistically 243 significant differences in EL were found in few accessions ( $p<0.05$ ) (Fig. 3). EL ratio of the 244 accessions ranged from 0.949 to 1.324 (mean EL ratio 1.07). The lowest ratio was recorded for 245 accessions Es-1 while the highest for Es-5 (Fig. 3).

246 Compared with control, the salt-treated group had significantly less chlorophyll $(\mathrm{p}<0.05)$. The 247 mean chlorophyll content values for control and treated groups were $18.17 \pm 4.79$ and $14.06 \pm 6.02$ 248 CCI, respectively (Table 2). Under salt stress, chlorophyll content of the accessions was highly 249 variable. Compared to their respective control, 4 accessions showed a significant SPAD increase, 25017 accessions showed a significant decrease while 4 accessions did not show any significant 251 SPAD change under salt stress $(\mathrm{p}<0.05)$ (Table 2$)$.

252

\section{Gas exchange attributes}

254 Salt stress caused a marked and significant reduction in net photosynthesis rate (PR) in all 255 accessions $(p<0.05)$. PR in control was $7.5 \pm 4.69 \mu \mathrm{mol} \mathrm{m}^{-2} \mathrm{~s}^{-1}$ while in treated group it was only $2561.91 \pm 0.97 \mu \mathrm{mol} \mathrm{m}^{-2} \mathrm{~s}^{-1}$ (Table 3 ). A significant variation was shown by the accessions in this 257 attribute $(p<0.05)$. At $0 \mathrm{mM} \mathrm{NaCl}$, Es-3 and Es-17 had maximum and minimum PR, respectively 258 while at $150 \mathrm{mM} \mathrm{NaCl}$, Es- 1 and Es- 25 showed the maximum and minimum PR, respectively 259 (Table 3).

260 Over all, no significant differences were found in mean intercellular $\mathrm{CO}_{2}$ concentration $(\mathrm{Ci})$ 261 between control and treatment groups $(p>0.05)$. Mean $\mathrm{Ci}$ values in control and treatment groups 262 were $281.2 \pm 22.9 \mu \mathrm{mol} \mathrm{mol}^{-1}$ and $284.7 \pm 42.6 \mu \mathrm{mol} \mathrm{mol}^{-1}$, respectively (Table 3). However, 263 significant inter-accession variations in $\mathrm{Ci}$ were detected in both control and treatment groups $264(p<0.05)$. The Ci ranged from 238 to $340 \mu \mathrm{mol} \mathrm{mol}^{-1}$ in control group while from 215.5 to 361 $265 \mu \mathrm{mol} \mathrm{mol}^{-1}$ in treatment group (Table 3). Es-20 and Es-17 showed the highest and the lowest Ci 266 among control group while Es-24 and Es-15 showed the highest and the lowest Ci among 267 treatment group (Table 3).

268 The transpiration rate (TR) in the salt-stressed group was significantly lower compared with the 269 control group $(\mathrm{p}<0.05)$. Mean TR values for control and treated groups were $2.57 \pm 1.13 \mathrm{mmol} \mathrm{m}^{-}$ $2702^{2} \mathrm{~s}^{-1}$ and $0.94 \pm 0.48 \mathrm{mmol} \mathrm{m}^{-2} \mathrm{~s}^{-1}$, respectively (Table 3). In control plants TR ranged from 0.91 271 (Es-2) to $4.18 \mathrm{mmol} \mathrm{m}^{-2} \mathrm{~s}^{-1}$ (Es-3) while in salt-stressed plants it ranged from 0.26 (Es-15) to 1.94 $272 \mathrm{mmol} \mathrm{m}^{-2} \mathrm{~s}^{-1}$ (Es-5) (Table 3). 
273 The salt-stressed group exhibited significantly reduced stomatal conductance (SC) compared

274 with the control group $(\mathrm{p}<0.05)$. Mean SC values for control and treated groups were $0.14 \pm 0.08$

$275 \mathrm{mmol} \mathrm{m}^{-2} \mathrm{~s}^{-1}$ and $0.04 \pm 0.02 \mathrm{mmol} \mathrm{m}^{-2} \mathrm{~s}^{-1}$, respectively (Table 3). Significant inter-accession

276 variations were also observed in $\mathrm{SC}$ within control as well as treatment groups $(\mathrm{p}<0.05)$. SC, in 277 control group, ranged from $0.04 \mathrm{mmol} \mathrm{m}^{-2} \mathrm{~s}^{-1}$ to $0.31 \mathrm{mmol} \mathrm{m}^{-2} \mathrm{~s}^{-1}$. Es-3 and Es-2 exhibited the

278 highest and the lowest SC (Table 3). On the other hand, SC in treatment group ranged from 0.01 $279 \mathrm{mmol} \mathrm{m}^{-2} \mathrm{~s}^{-1}$ to $0.075 \mathrm{mmol} \mathrm{m}^{-2} \mathrm{~s}^{-1}$; Es-12 and Es-15 exhibiting the highest and the lowest SC, 280 respectively. The accession Es-2 exhibited an interesting phenotype; SC under control and salt 281 stress was not significantly different (Table 3 ). Gas exchange parameters could not be assayed in 282 two accessions (Es-7 and Es-16) due to the unavailability of enough seeds.

283

284

285

286

287

288

289

290

291

292

293

294

295

296

297

298

299

300

301

302

303

304

305

306

307

308

309

310

311

\section{Mineral ion content}

Significantly higher $\mathrm{Na}^{+}$accumulated in salt-stressed plants compared with control $(\mathrm{p}<0.05)$. Mean $\mathrm{Na}^{+}$content values for control and treated groups were $13.52 \pm 5.01$ and $29.55 \pm 8.8 \mathrm{mg} / \mathrm{g}$ DW, respectively (Table 4). Significant inter-accession variations were found in $\mathrm{Na}^{+}$content in both control and treatment groups $(\mathrm{p}<0.05)$. In control group, $\mathrm{Na}^{+}$content varied from 4.6 to $24.90 \mathrm{mg} / \mathrm{g}$ DW; Es-1 and Es-21 showing the lowest and the highest $\mathrm{Na}^{+}$content, respectively (Table 4). $\mathrm{Na}^{+}$content, in treatment group, ranged from 16.99 to $48.11 \mathrm{mg} / \mathrm{g} \mathrm{DW}$; accessions Es3 and Es-20 accumulated the lowest and the highest $\mathrm{Na}^{+}$, respectively (Table 4).

Salt-stressed group, compared with control, exhibited a moderate but statistically significant increase in $\mathrm{K}^{+}$content $(\mathrm{p}<0.05)$. The mean $\mathrm{K}^{+}$content values for control and treatment groups were $15.61 \pm 6.08 \mathrm{mg} / \mathrm{g}$ DW and $19.44 \pm 7.46 \mathrm{mg} / \mathrm{g}$ DW, respectively (Table 4). Furthermore, in both control and treated groups, accessions showed significant variability in $\mathrm{K}^{+}$content. The $\mathrm{K}^{+}$ content in control group varied from 6.95 to $33.40 \mathrm{mg} / \mathrm{g}$ DW while in treatment group from 9.74 to $41.30 \mathrm{mg} / \mathrm{g}$ DW (Table 4). In control as well as stressed group, Es-4 and Es-9 exhibited the lowest and the highest $\mathrm{K}^{+}$content, respectively (Table 4).

$\mathrm{K}^{+} / \mathrm{Na}^{+}$ratio was significantly decreased in the salt-treated group as compared with control $(p<0.05)$. The mean $\mathrm{K}^{+} / \mathrm{Na}^{+}$ratio in control and treatment groups was $1.22 \pm 0.36$ and $0.67 \pm 0.2$, respectively (Table 4). Accessions exhibited diverse trends for $\mathrm{K}^{+} / \mathrm{Na}^{+}$ratio which ranged from 0.63-2.07 and 0.44-1.3 in control and treated plants, respectively (Table 4). To further distinguish the accessions in which $\mathrm{K}^{+} / \mathrm{Na}^{+}$ratio was least affected by the salt stress, $\mathrm{K}^{+} / \mathrm{Na}^{+}$ratio was expressed as the stress index. As shown in fig. 4, accessions Es-23, Es-15, and Es-11 showed the highest while Es-1, Es-10, and Es-20 the lowest $\mathrm{K}^{+} / \mathrm{Na}^{+}$ratio stress index (Fig. 4). We also determined two other important cations $\mathrm{Ca}^{2+}$ and $\mathrm{Mg}^{2+}$ in E. sativa accessions. Saltstressed group accumulated significantly more $\mathrm{Ca}^{2+}$ than the control group $(\mathrm{p}<0.05)$ (Control mean $6.03 \pm 2.63 \mathrm{mg} / \mathrm{g}$ DW vs treated mean $9.08 \pm 5.34 \mathrm{mg} / \mathrm{g}$ DW) (Table 4). Accessions, growing under controlled conditions as well as under $\mathrm{NaCl}$ treatment, showed significant variations in $\mathrm{Ca}^{2+}$ content $(\mathrm{p}<0.05)$ (Table 4). $\mathrm{Ca}^{2+}$ content, in the control group varied from 2.61 to 13.47 $\mathrm{mg} / \mathrm{g}$ DW while, for the treatment group, it varied from 2.87 to $23.17 \mathrm{mg} / \mathrm{g}$ DW (Table 4). 
312 Salt-stressed group showed significantly low $\mathrm{Mg}^{2+}$ content compared with control group 313 ( $\mathrm{p}<0.05$ ). Mean $\mathrm{Mg}^{2+}$ content for the control group was $5.35 \pm 2.86 \mathrm{mg} / \mathrm{g}$ DW while for the salt 314 treatment group it was $4.06 \pm 1.84 \mathrm{mg} / \mathrm{g}$ DW (Table 4). Significant variations in $\mathrm{Mg}^{2+}$ content 315 were observed among accessions growing under controlled conditions as well as under $\mathrm{NaCl}$ 316 treatment (Table 4). $\mathrm{Mg}^{2+}$ content, of the control group, ranged from 2.74 to $14.25 \mathrm{mg} / \mathrm{g} \mathrm{DW}$ 317 while in the treatment group from 2.28 to $9.95 \mathrm{mg} / \mathrm{g}$ DW (Table 4).

318

\section{Principal component analysis}

The principal component analysis (PCA) was performed on mean MFV values of morphophysiological traits to understand the weightage of each trait towards observed variation. Overall, PCA1 and PCA2 represented $52.66 \%$ of the observed variation whereas individually PCA1 and PCA2 accounted for $39.96 \%$ and $12.7 \%$ of the variation, respectively (Fig. 5a). The most significant traits for PC1 were PH, SL, RL, LN, LA, FW, and DW while for PC2, PR, and EL were the most significant traits as these accounted for higher contributions towards $\mathrm{PC} 2$ (loadings $\geq 0.30$ ). $\mathrm{K}^{+} / \mathrm{Na}^{+}$ratio was the least significant trait for both $\mathrm{PC} 1$ and PC2 (Fig. $5 b$ ).

\section{Ranking and grouping of $E$. sativa accessions for evaluation of salt tolerance}

For determination of the extent of variation in salinity tolerance among $E$. sativa accessions, the data of morpho-physiological traits (for control and treatment) were standardized by calculating the salt tolerance index (STI) which is the ratio of the value for the $\mathrm{NaCl}$ treated plant/value for the control. STI was then used for computing the membership function values (MFV) of $E$. sativa accessions. The following traits were used for MFV calculation: SL, RL, PH, LN, LA, $\mathrm{FW}, \mathrm{DW}, \mathrm{SPAD}, \mathrm{EL}, \mathrm{K}^{+} / \mathrm{Na}^{+}$ratio, and PR. Moreover, Pearson's correlation analysis was done for the determination of the relationship among traits. As shown in fig. 6, a strong and highly significant correlations were found among morphological traits like RL, SL, and PH $(p<0.001)$. Leaf attributes also showed strong correlations. LN showed significant correlation with $\mathrm{PH}, \mathrm{RL}$ $(\mathrm{p}<0.001)$, SL, LA, DW $(\mathrm{p}<0.01)$ and FW $(\mathrm{p}<0.05)$. LA exhibited a strong correlation with SL $(\mathrm{p}<0.01)$ and $\mathrm{PH}(\mathrm{p}<0.05)$. FW and DW were also strongly correlated $(\mathrm{p}<0.001) . \mathrm{K}^{+} / \mathrm{Na}^{+}$ratio also exhibited significant correlations with PH, RL $(p<0.01)$ and SL $(p<0.05)$. Three of the tested traits i.e. EL, SPAD, and PR did not show any significant correlation (Fig. 6).

The ranking of the degree of salt tolerance among E. sativa accessions was done based on MFV. The higher mean MFV represents higher salt tolerance and vice versa. MFV data of the accessions are presented in Table 5. Mean and standard deviation (S.D) of overall MFV data were 0.43 and 0.11, respectively. The highest MFV score was observed for Es-11 (0.62, highly tolerant) while the lowest score for Es-3 (0.18, highly sensitive). Furthermore, E. sativa accessions were categorized into five standard groups according to the previously described criteria (Chen et al., 2012). Among 25 accessions, one accession was ranked as highly tolerant (MFV $\geq 0.62)$, four as tolerant $(0.55 \leq \mathrm{MFV}<0.62)$, fifteen as moderately tolerant $(0.33 \leq \mathrm{MFV}<0.55)$, four as sensitive $(0.26 \leq \mathrm{MFV}<0.33)$ while one accession as highly sensitive $(\mathrm{MFV}<0.26)$. Accession Es-11 was ranked as highly tolerant while accessions Es-1, Es-9, Es-12, 
352

353

354

355

356

357

358

359

360

361

362

363

364

365

366

367

368

369

370

371

372

373

374

375

376

377

378

379

380

381

382

383

384

385

386

387

388

389

390

391

and Es-19 as tolerant. Es-3 was ranked as highly sensitive while Es-15, Es-16, Es-17, and Es-18 as sensitive. The remaining fifteen accessions were placed in moderately tolerant group (Table $5)$.

Furthermore, the MFV data was used to construct a similarity matrix based on Euclidean distance (Fig. 7). The accessions were separated into four distinct clusters; two smaller clusters (clusters 1 and 4 ) and two larger clusters (clusters 2 and 3). Clusters 1 and 4 consisted of 3 and 5 accessions, respectively, while clusters 2 and 3 consisted of 8 and 9 accessions, respectively. Es9, Es-11, and Es-12 were placed in cluster 1. The members of cluster 2 included Es-5, Es-8, and Es-20 to Es-25. The largest cluster i.e. cluster 3 comprised of the following members: Es-1, Es-2, Es-4, Es-6, Es-7, Es-10, Es-13, Es-14, and Es-19. Five accessions namely Es-3, Es-15, Es-16, Es-17, and Es-18 were included in cluster 4 (Fig. 7).

\section{Discussion}

It is well known that salt stress negatively affects plant growth and development attributes like plant height and biomass in many plant species resulting in significant yield losses (Munns \& Tester, 2008; Arzani \& Ashraf, 2016). E. sativa can grow in poor fertility lands and exhibit tolerance to various abiotic stresses including salinity (Ashraf, 1994; Shannon \&Grieve, 1999; Garg \& Sharma 2014). In the current research, we thoroughly assessed the 25 E. sativa accessions to determine the extent of genetic variation in salt tolerance based on 11 morphophysiological traits. The growth and development traits like RL, SL, PH, LN, LA, FW, and DW were significantly reduced in stressed plants compared with control (Figs. $1 \& 2$, Table 1). The growth inhibition could be the result of ion toxicity, nutrients imbalance, osmotic stress, the decline in photosynthesis rate, and changes in stomatal conductance (Munns \& Tester, 2008; Fageria et al., 2012). The reduction in leaf number and leaf area under salt stress could be a physiological response of the plant to prevent excessive water loss (Parida \& Das, 2005). Salt stress significantly reduced plant height, shoot biomass, and leaf area in six rocket genotypes (Petretto et al., 2019). Similar data regarding the effect of salt stress on growth parameters in $E$. sativa was also reported by Bakhshandeh et al., (2019). The data presented in the current research are in good agreement with the above-cited studies.

RWC is a key marker and could be applied as a simple indicator for screening plant salt tolerance. By maintaining RWC under stress conditions, plant resumes metabolic activities and continues growth and development in saline conditions (Slabbert \& Krüger, 2014). In our study, mean RWC values for control and treated groups were not significantly different however moderate variations in RWC between control and its treated counterpart were observed for few accessions (Table 2). According to Ashraf (1994), RWC was not significantly different between the tolerant and sensitive E. sativa cultivars under salt stress. In another study, E. sativa cv Astro did not exhibit any significant change in RWC up to $100 \mathrm{mMol} / \mathrm{L} \mathrm{NaCl}$ however it was significantly reduced at 200 and $300 \mathrm{mmol} / \mathrm{L} \mathrm{NaCl}$ (Hniličková et al., 2017). On the other hand, in a study by Al Gehani \& Ismail (2016), significant changes in RWC in E. sativa were evident at $40 \mathrm{mMol} / \mathrm{L} \mathrm{NaCl}$. In the light of our data and above-cited studies, it seems that although $E$. 
392

393

394

395

396

397

398

399

400

401

402

403

404

405

406

407

408

409

410

411

412

413

414

415

416

417

418

419

420

421

422

423

424

425

426

427

428

429

430

431

sativa has a general tendency to maintain RWC under moderate salt stress however significant variation in this trait also seems to exist.

The electrolyte leakage can be triggered by different stresses including salinity. These stresses lead to increased ROS production which damages cell membrane causing more electrolyte leakage (Demidchik et al., 2003; Demidchik et al., 2010). It is regarded as one of the main selection criteria for identifying salt tolerant plants (Ashraf \& Ali, 2008). ROS can be detoxified in plants by up-regulating the antioxidant enzymes and by non- enzymatic antioxidants. According to our data, only a minute increase in EL was observed for few accessions in salt stress (which is evident from treated/ control EL ratio close to 1 for most of the accessions) (Fig. 3). The mean EL ratio for all the accessions was 1.07 which shows that plants might not be undergoing any extensive membrane damage. It seems that E. sativa accessions exhibit a good level of tissue tolerance and protect the membrane from any significant damage.

It is generally believed that salt stress causes a decrease in chlorophyll content (Khoshbakht et al., 2015; Qiu et al., 2017). Some reports have, however, shown an increase in chlorophyll content for a few plant species under salt stress (Stefanov et al., 2016; Shah et al., 2017). In current study we observed an overall reduction in chlorophyll content in treatment group compared with control. As presented in Table 2, the mean chlorophyll content of the stressed group was significantly lower than control $(\mathrm{p}<0.05)$. However, at accession level response was variable; in most of the accessions (68\%) salt stress triggered a decline in chlorophyll content while in $16 \%$ accessions chlorophyll did not significantly change (Table 2 ). The remaining 16\% accessions exhibited an increase in chlorophyll content under salt stress (Table 2). According to these data, although a decline in chlorophyll content was a general trend however, at accession level, the response was variable.

It is known that transpiration rate, stomatal conductance, intercellular $\mathrm{CO}_{2}$ concentration, and photosynthesis rate are negatively affected by salt stress (Sudhir \& Murthy, 2004; Chaves et al., 2009; Ullah et al., 2019). Salt stress induced inhibition of photosynthesis could be the result of stomatal as well as nonstomatal factors ( $X u \&$ Zhou, 2008; Saibo et al., 2009). The latter include inhibition of Rubisco, reduced regeneration of Ribulose-1,5- bisphosphate, and hindrances in internal $\mathrm{CO}_{2}$ conductance (von Caemmerer \& Farquhar, 1981). In some cases, non-stomatal factors are more responsible for the decrease in photosynthesis (Jacob \& Lawlor, 1991). We have shown that PR, SC, and TR were markedly reduced in salt-stressed plants while Ci was the least affected gas exchange parameter (Table 3). A comparatively less pronounced effect of salinity on $\mathrm{Ci}$ shows that possibly non-stomatal factors could be the major contributors to PR reduction in E. sativa accessions. If this was not the case, we might have observed a higher decline in $\mathrm{Ci}$ along with other gas exchange parameters. Similar findings have been reported in rice wherein significantly higher $\mathrm{Na}^{+}$accumulation in leaves reduced stomatal conductance and photosynthesis without significantly affecting the Ci (Yeo et al., 1991). Hniličková et al., (2017) reported a significant reduction in all gas exchange parameters by salt stress in E. sativa.

Interestingly Ci remained unaffected in salt-stressed plants till $100 \mathrm{mM} / \mathrm{L} \mathrm{NaCl}$ but was significantly reduced at higher concentrations (above $200 \mathrm{mM} / \mathrm{L} \mathrm{NaCl}$ (Hniličková et al., 2017). 
432 Since we used $150 \mathrm{mM} \mathrm{NaCl}$ in our study, it could be possible that Ci reduction takes place at 433 higher $\mathrm{NaCl}$ concentrations. Overall, our findings are in agreement with those reported by 434 Hniličková et al., (2017).

435 It has been reported that exposure to $\mathrm{NaCl}$ disturbs the homeostasis of cations like $\mathrm{Na}^{+}, \mathrm{Mg}^{+2}$, $436 \mathrm{Ca}^{+2}$, and $\mathrm{K}^{+}$in plants (Rabie et al., 2005). $\mathrm{Na}^{+}$and $\mathrm{K}^{+}$homeostasis is crucial for plants salt 437 tolerance (Chen et al., 2007). Most of the plant species are susceptible to elevated concentrations 438 of $\mathrm{Na}^{+}$because it results in ion toxicity and osmotic stress (Horie et al., 2009). It is also well 439 known that $\mathrm{K}^{+}$is the most crucial monovalent cation for many plant processes (Benito et al., 440 2014). Salt tolerant plants have efficient mechanisms in place for the sequestration of $\mathrm{Na}^{+}$or the 441 elevation of cytoplasmic $\mathrm{K}^{+}$levels relative to $\mathrm{Na}^{+}$(Gierth \& Mäser, 2007; Horie et al., 2009). 442 Our data shows that, compared with the control group's mean, about two-fold higher $\mathrm{Na}^{+}$ 443 accumulated in salt treated group (Table 4). These data show that $E$. sativa could be an includer 444 type and it might possess an active $\mathrm{Na}^{+}$tolerance mechanism. We have reported a moderate but 445 statistically significant increase in $\mathrm{K}^{+}$concentration in the salt-treated group as compared with 446 control (Table 4) which shows that possibly E. sativa possesses mechanisms for retaining/ 447 accumulating $\mathrm{K}^{+}$under salt stress. It has been reported that barley accessions actively retain $\mathrm{K}^{+}$ 448 under salt stress (Genc et al., 2007). Salt stress-induced $\mathrm{K}^{+}$elevation has also been previously reported for a tolerant wheat genotype, barley, watermelon and quinoa (shabala et al., 2010;

451

452

453

454

455

456

457

458

459

460

461

462

463

464

465

466

467

468

469

470

471 Orsini et al., 2011; Hariadi et al., 2011; Adolf et al., 2013; Ekbic et al., 2017; Dugasa et al., 2018). Tissue tolerance to $\mathrm{Na}^{+}$accumulation and $\mathrm{K}^{+}$retention under salt stress could be important factors for salt tolerance in E. sativa.

Plants are known to exhibit diversity in salt stress tolerance (Sabir et al., 2011; Al-Ashkar et al., 2019; Wu et al., 2019; Mohamed et al., 2020; Benabderrahim et al., 2020). E. sativa has been reported to exhibit significant genetic diversity (Slater, 2013). The evaluation of different $E$. sativa genotypes holds great promise for future breeding programs (Petretto et al., 2019). In the current research, we thoroughly characterized $25 \mathrm{E}$. sativa accessions to determine the extent of genetic variation in salt tolerance based on 11 morpho-physiological traits. Significant interaccession variability was observed in all the tested traits (Table 5). Different traits showed different rankings of accessions for salt tolerance, indicating genetic diversity among $E$. sativa accessions. The contribution of the individual traits in observed variability could not be necessarily the same; few traits could be more contributing than others toward overall variability. PCA is an effective tool for dissecting the traits according to their contribution in variability and has been applied to screen the traits in previous studies on salt tolerance (Barhoumi, 2019; AlAshkar et al., 2019; Benabderrahim et al., 2020; Efisue \& Dike, 2020). In the current research, PCA identified PH, SL, RL, LN, LA, FW, DW, PR, and EL as the most significant traits (loadings $\geq 0.30$ ) since these accounted for maximum inter-accession variation (Fig. 5). These traits could, therefore, be used for any larger scale $E$. sativa germplasm screening in the future. For screening of salt tolerance, different methods based on multiple trait results have been used (Kholghi et al., 2018; Hussain et al., 2013; Long et al., 2013). Among these, MFV is an effective screening method (Mohamed et al., 2020), which has been previously applied for ranking 
472 germplasm for drought tolerance (Chen et al., 2012) and salt tolerance (Wu et al., 2019). In the 473 current study, 25 E. sativa accessions were ranked according to the degree of salt tolerance (as

474 reflected by their MFV score). As shown in Table 5, 4\% of the accessions were ranked as highly 475 tolerant, $16 \%$ as tolerant, $60 \%$ as moderately tolerant, $16 \%$ as sensitive, and $4 \%$ as highly 476 sensitive. Moreover, the results of cluster analysis were largely in agreement with the MFV477 based categorization (Fig. $7 \&$ Table 5). Interestingly, all the sensitive/ highly sensitive 478 accessions were placed together in cluster 4. Similarly, one highly tolerant and two tolerant 479 accessions were placed in cluster 1 . All the tolerant/ moderately tolerant accessions were placed 480 in clusters 2 and 3 (Fig. $7 \&$ Table 5).

481

482

\section{Conclusions}

483

484

485

486

487

488

489

490

491

492

493

494

495

496

497

498

499

500

501

502

503

504

505

506

507

508

509

510

Salt stress significantly affected most of the morpho-physiological traits. We identified a few traits which could be most effective in resolving the inter-accession variability. Using the membership function value of tested traits, E. sativa accessions were ranked according of their salt tolerance. The accessions exhibited significant variations in the extent of salt stress tolerance. The tolerant accessions could be good material for future breeding programs aiming to improve salt tolerance. Further insights into the salt tolerance mechanism could be gained through carrying out the comparative transcriptomics in highly tolerant and sensitive accessions under salt stress conditions.

\section{Acknowledgements}

The authors acknowledge Bio-Resources Conservation Institute, National Agricultural Research Centre, Pakistan Agricultural Research Council, Islamabad, for kindly providing seeds of $E$. sativa accessions.

\section{References}

1. Acosta-Motos JR, Ortuño MF, Bernal-Vicente A, Diaz-Vivancos P, Sanchez-Blanco MJ, Hernandez JA (2017) Plant responses to salt stress: adaptive mechanisms. Agronomy 7: 18.

2. Adolf VI, Jacobsen SE, Shabala S (2013) Salt tolerance mechanisms in quinoa (Chenopodium quinoa Willd). Environ Exp Bot 92: 43-54.

3. Al Gehani I, Ismail TM (2016) Effect of soil amendment on growth and physiological processes of rocket (Eruca sativa L.) grown under salinity conditions. Aust J Basic Appl Sci 10: 15-20.

4. Al-Ashkar I, Alderfasi A, El-Hendawy S, Al-Suhaibani N, El-Kafafi S, Seleiman MF (2019) Detecting salt tolerance in doubled haploid wheat lines. Agronomy 9: 211.

5. Arzani A, Ashraf M (2016) Smart engineering of genetic resources for enhanced salinity tolerance in crop plants. Crit Rev Plant Sci 35: 146-189. 
511

512

513

514

515

516

517

518

519

520

521

522

523

524

525

526

527

528

529

530

531

532

533

534

535

536

537

538

539

540

541

542

543

544

545

546

547

548

549

550

6. Ashraf M (1994) Organic substances responsible for salt tolerance in Eruca sativa. Biol. Plant 36: 255-259.

7. Ashraf M, Ali Q (2008) Relative membrane permeability and activities of some antioxidant enzymes as the key determinants of salt tolerance in canola (Brassica napus L.). Environ Exp Bot 63: 266-273.

8. Azarenko O, Jordan M, Wilson L (2014) Erucin, the Major Isothiocyanate in Arugula (Eruca sativa), Inhibits Proliferation of MCF7 Tumor Cells by Suppressing Microtubule Dynamics. PloS One 9: 6, e100599.

9. Bakhshandeh E, Pirdashti H, Vahabinia F Gholamhosseini M (2019) Quantification of the effect of environmental factors on seed germination and seedling growth of Eruca (Eruca sativa) using mathematical models. J Plant Growth Regul 39: 190-204.

10. Bandeh A, Toorchi M, Kholghi M, Shakiba MR (2018) An evaluation of canola genotypes under salinity stress at vegetative stage via morphological and physiological traits. Pak. J. Bot. 50(2): 447-55.

11. Barhoumi Z (2019) Agro-morphological characterization of 31 barley accessions after $\mathrm{NaCl}$ treatment. Int J Environ Sci Te 16(10): 5525-5536.

12. Benabderrahim MA, Guiza M, Haddad M (2020) Genetic diversity of salt tolerance in tetraploid alfalfa (Medicago sativa L.). Acta Physiol Plant 42: 5.

13. Benito B, Haro R, Amtmann A, Cuin TA, Dreyer I (2014) The twins $\mathrm{K}^{+}$and $\mathrm{Na}^{+}$in plants. J plant physiol 171: 723-731.

14. Bhardwaj S, Sharma NK, Srivastava PK, Gaurav S (2010) Salt tolerance assessment in alfalfa (Medicago sativa L.) ecotypes. Bot Res J 3(1):1-6

15. Chaves MM, Flexas J, Pinheiro C (2009) Photosynthesis under drought and salt stress: regulation mechanisms from whole plant to cell. Ann Bot 103: 551-560.

16. Chen X, Min D, Yasir TA, Hu YG (2012) Evaluation of 14 morphological, yield-related and physiological traits as indicators of drought tolerance in Chinese winter bread wheat revealed by analysis of the membership function value of drought tolerance (MFVD). Field Crops Res 137: 195-201.

17. Chen Z, Zhou M, Newman IA, Mendham NJ, Zhang G, Shabala S (2007) Potassium and sodium relations in salinized barley tissues as a basis of differential salt tolerance. Funct Plant Biol 3: 150-162.

18. Demidchik V, Cuin TA, Svistunenko (2010) Arabidopsis root $\mathrm{K}^{+}$efflux conductance activated by hydroxyl radicals: single-channel properties, genetic basis and involvement in stress-induced cell death. J Cell Sci 123: 1468-1479.

19. Demidchik V, Shabala SN, Coutts KB, Tester MA, Davies JM (2003) Free oxygen radicals regulate plasma membrane $\mathrm{Ca}^{2+}$ and $\mathrm{K}^{+}$permeable channels in plant root cells. $\mathrm{J}$ Cell Sci 116: 81-88.

20. Dugasa MT, Cao F, Ibrahim W, Wu F (2018) Differences in physiological and biochemical characteristics in response to single and combined drought and salinity stresses between wheat genotypes differing in salt tolerance. Physiol Plant 165: 134-143. 
551

552

553

554

555

556

557

558

559

560

561

562

563

564

565

566

567

568

569

570

571

572

573

574

575

576

577

578

579

580

581

582

583

584

585

586

587

588

21. Efisue AA, Dike CC (2020) Screening rice (Oryza sativa L.) for salinity tolerance for yield and yield components in saline stressed environment. Amer J Agri Forestry 8: 15-21.

22. Ekbic E, Cagri C, Kürşat K, Kose MA, Aras V (2017) Assessment of watermelon accessions for salt tolerance using stress tolerance indices. Ciência e Agrotecnologia 41: 616-625.

23. Fageria NK, Stone LF, Santos ABD (2012) Breeding for salinity tolerance. In: FritscheNeto, R., Borem, A. (Eds.), Plant Breeding for Abiotic Stress Tolerance. Springer-Verlag, Berlin 103-122.

24. Garg G, Sharma V (2014) Eruca sativa (L.): Botanical description, crop improvement, and medicinal properties. J Herbs Spices Med Plants 20: 171-182.

25. Genc Y, McDonald GK, Tester M (2007) Reassessment of tissue $\mathrm{Na}^{+}$concentration as a criterion for salinity tolerance in bread wheat. Plant Cell Environ 30: 1486-1498.

26. Gierth M, Mäser P (2007) Potassium transporters in plants-involvement in $\mathrm{K}^{+}$acquisition, redistribution and homeostasis. FEBS Letters, 581: 2348-2356.

27. Gupta B, Huang B (2014) Mechanism of salinity tolerance in plants: physiological, biochemical, and molecular characterization. Int J Genomics 2014:701596. doi:

$10.1155 / 2014 / 701596$

28. Hariadi Y, Marandon K, Tian Y, Jacobsen SE, Shabala S (2011) Ionic and osmotic relations in quinoa (Chenopodium quinoa Willd.) plants grown at various salinity levels. J Exp Bot 62: 185-193.

29. Hniličková H, Hnilička F, Jaroslava M, Kamil K (2017) Effects of salt stress on water status, photosynthesis and chlorophyll fluorescence of rocket. Plant Soil Environ 63: 362367.

30. Hoagland DR, Arnon DI (1938) The water culture method for growing plants without soil. California Agricultural Experiment Station Circulation 347: 32.

31. Horie T, Hauser F, Schroeder JI (2009) HKT transporter-mediated salinity resistance mechanisms in Arabidopsis and monocot crop plants. Trends Plant Sci 14: 660-668.

32. Ismail AM, Horie T (2017) Genomics, physiology, and molecular breeding approaches for improving salt tolerance. Ann Revi Plant Biol 68: 405-434.

33. Jacob J, Lawlor DW (1991) Stomatal and mesophyll limitations of photosynthesis in phosphate deficient sunflower, maize and wheat plants. J Exp Bot 42(8): 1003-1011.

34. Khoobchandani M, Ojeswi B, Ganesh N, Srivastava M, Gabbanini, Matera R, Iori R, Valgimigli L (2010) Antimicrobial properties and analytical profile of traditional Eruca sativa seed oil: Comparison with various aerial and root plant extracts. Food Chem 120: 217-224.

35. Khoshbakht D, Ramin AA, Baninasab B (2015) Effects of sodium chloride stress on gas exchange, chlorophyll content and nutrient concentrations of nine citrus rootstocks. Photosynthetica 53: 241-249. 
589

590

591

592

593

594

595

596

597

598

599

600

601

602

603

604

605

606

607

608

609

610

611

612

613

614

615

616

617

618

619

620

621

622

623

624

625

626

627

36. Li T, Hu Y, Du X, Tang H, Shen C, Wu J (2014) Salicylic acid alleviates the adverse effects of salt stress in Torreya grandis cv. Merrillii seedlings by activating photosynthesis and enhancing antioxidant systems. PLOS one 9(10).

37. Long WH, Pu HM, Zhang JF, Qi CK, Zhang XK (2013) Screening of Brassica napus for salinity tolerance at germination stage. Chin. J. Oil Crop Sci. 35:271-275.

38. Loutfy N, El-Tayeb MA, Hassanen AM, Moustafa MFM, Sakuma Y, Inouhe M (2012) Changes in the water status and osmotic solute contents in response to drought and salicylic acid treatments in four different cultivars of wheat (Triticum aestivum). J Plant Res 12: 173-184.

39. Machado RM, Serralheiro RP (2017) Soil salinity: effect on vegetable crop growth. Management practices to prevent and mitigate soil salinization. Horticulturae 3(2):30.

40. Mohamed A, Ibrahim A, Shalby N, Bai C, Qin M, Agami RA, Jie K, Wang B, Zhou G (2020) Stomatal and Photosynthetic Traits Are Associated with Investigating Sodium Chloride Tolerance of Brassica napus L. Cultivars. Plants 9(1):62.

41. Munns R, Tester M (2008) Mechanisms of salinity tolerance. Ann Rev Plant Biol 59: 651681.

42. Orsini F, Accorsi M, Gianquinto G, Dinelli G, Antognoni F, Karina, Carrasco R, Enrique Az, Alnayef M, Marotti I (2011) Beyond the ionic and osmotic response to salinity in Chenopodium quinoa: functional elements of successful halophytism. Funct Plant Biol 38: 818-831.

43. Oyiga BC, Sharma RC, Shen J, Baum M, Ogbonnaya FC, Léon J, Ballvora A (2016) Identification and characterization of salt tolerance of wheat germplasm using a multivariable screening approach. J Agron Crop Sci 202(6), 472-485.

44. Parida AK, Das AB (2005) Salt tolerance and salinity effects on plants: a review. Ecotoxicol Environ Saf 60: 324-349.

45. Petretto GL, Urgeghe PP, Massa D, Melito S (2019) Effect of salinity ( $\mathrm{NaCl}$ ) on plant growth, nutrient content, and glucosinolate hydrolysis products trends in rocket genotypes. Plant Physiol Biochem 141: 30-39.

46. Pignone D, Gomez-Campo C (2011) Eruca In: Kole C (ed) Wild crop relatives: genomic and breeding resources, oilseeds. Springer, Heidelberg

47. Qiu T, Jiang L, Li S, Yang Y (2017) Small-scale habitat-specific variation and adaptive divergence of photosynthetic pigments in different alkali soils in reed identified by common garden and genetic tests. Front Plant Sci 7: 2016.

48. Rabie GH, Aboul-Nasr MB, Al-Humiany A (2005) Increased salinity tolerance of cowpea plants by dual inoculation of an arbuscular mycorrhizal fungus Glomus clarum and a nitrogen-fixer Azospirillum brasilense. Mycobiology 33: 51-60.

49. Sabir P, Ashraf M, Akram NA (2011) Accession variation for salt tolerance in proso millet (Panicum miliaceum L.) using leaf proline content and activities of some key antioxidant enzymes. J Agron Crop Sci 197: 340-347. 
628

629

630

631

632

633

634

635

636

637

638

639

640

641

642

643

644

645

646

647

648

649

650

651

652

653

654

655

656

657

658

659

660

661

662

663

664

665

666

50. Saibo NJM, Lourenço T, Oliveira MM (2009) Transcription factors and regulation of photosynthetic and related metabolism under environmental stresses. Ann Bot 103: 609623.

51. Shabala S, Shabala S, Cuin TA, Pang J, Percey William P, Chen Z, Eing C, Wegner L H (2010) Xylem ionic relations and salinity tolerance in barley. Plant J 61: 839-853.

52. Shah SH, Houborg R, McCabe MF (2017) Response of Chlorophyll, Carotenoid and SPAD-502 measurement to salinity and nutrient stress in wheat (Triticum aestivum L.). Agronomy 7:1-20.

53. Shannon MC, Grieve CM (1999) Tolerance of vegetable crops to salinity. Sci. Hort. 78:536.

54. Shokri-Gharelo R, Noparvar PM (2018) Molecular response of canola to salt stress: insights on tolerance mechanisms. Peer J 22; 6: e4822.

55. Singh J, Singh V, Sharma PC (2018) Elucidating the role of osmotic, ionic and major salt responsive transcript components towards salinity tolerance in contrasting chickpea (Cicer arietinum L.) genotypes. Physiol Mol Biol Plants 24: 441-453

56. Slabbert MM, Krüger GH (2014) Antioxidant enzyme activity, proline accumulation, leaf area and cell membrane stability in water stressed Amaranthus leaves. S Afr J Bot 95:123128.

57. Slater SM (2013). Biotechnology of Eruca Sativa Mill. In Biotechnology of Neglected and Underutilized Crops (pp. 203-216). Springer, Dordrecht.

58. Stefanov M, Yotsova E, Rashkov G, Ivanova K, Markovska Y, Apostolova EL (2016)

Effects of salinity on the photosynthetic apparatus of two paulownia lines. Plant Physiol. Biochem. 2016, 101, 54-59.

59. Sudhir P, Murthy SD (2004) Effects of salt stress on basic processes of photosynthesis. Photosynthetica 42(2):481-486.

60. Ullah A, Li M, Noor J, Tariq A, Liu Y, Shi L (2019) Effects of salinity on photosynthetic traits, ion homeostasis and nitrogen metabolism in wild and cultivated soybean. Peer J 7:e8191 http://doi.org/10.7717/peerj.8191

61. Von Caemmerer SV, Farquhar GD (1981) Some relationships between the biochemistry of photosynthesis and the gas exchange of leaves. Planta. 153(4): 376-387.

62. Wani SH, Singh NB, Haribhushan A, Mir JI (2013) Compatible solute engineering in plants for abiotic stress tolerance-role of glycine betaine. Curr Genomics 14(3):157.

63. Wu H, Guo J, Wang C, Li K, Zhang X, Yang Z, Li M, Wang B (2019) An effective screening method and a reliable screening trait for salt tolerance of Brassica napus at the germination stage. Front Plant Sci 10: 530.

64. Xu ZZ, Zhou GS (2008) Responses of leaf stomatal density to water status and its relationship with photosynthesis in a grass. J Exp Bot 59: 3317-3325.

65. Yang Y, Guo Y (2018) Unraveling salt stress signaling in plants. J Integr Plant Biol 60: 796-804. 
667 66. Yeo AR, Lee $\Lambda$ S, Izard P, Boursier PJ, Flowers TJ (1991) Short-and long-term effects of 668 salinity on leaf growth in rice (Oryza sativa L.). J Exp Bot 42(7): 881-889.

669 67. Yildirim E, Karlidag H, Turan M (2009) Mitigation of salt stress in strawberry by foliar

670 $\mathrm{K}^{+}, \mathrm{Ca}^{+2}$ and $\mathrm{Mg}^{+2}$ nutrient supply. Plant Soil Environ 55: 213-221.

671 68. Zeng L, Shannon M, Grieve C (2002) Evaluation of salt tolerance in rice genotypes by

672 multiple agronomic parameters. Euphytica 127 (2): 235-245.

673 


\section{Figure 1}

Effect of salt stress on growth parameters in E. sativa (A) Shoot length stress index (B) Root length stress index (C) Plant height stress index (D) leaf number stress index (E) leaf area stress index

Values are mean $( \pm S D)$ of six replicates.

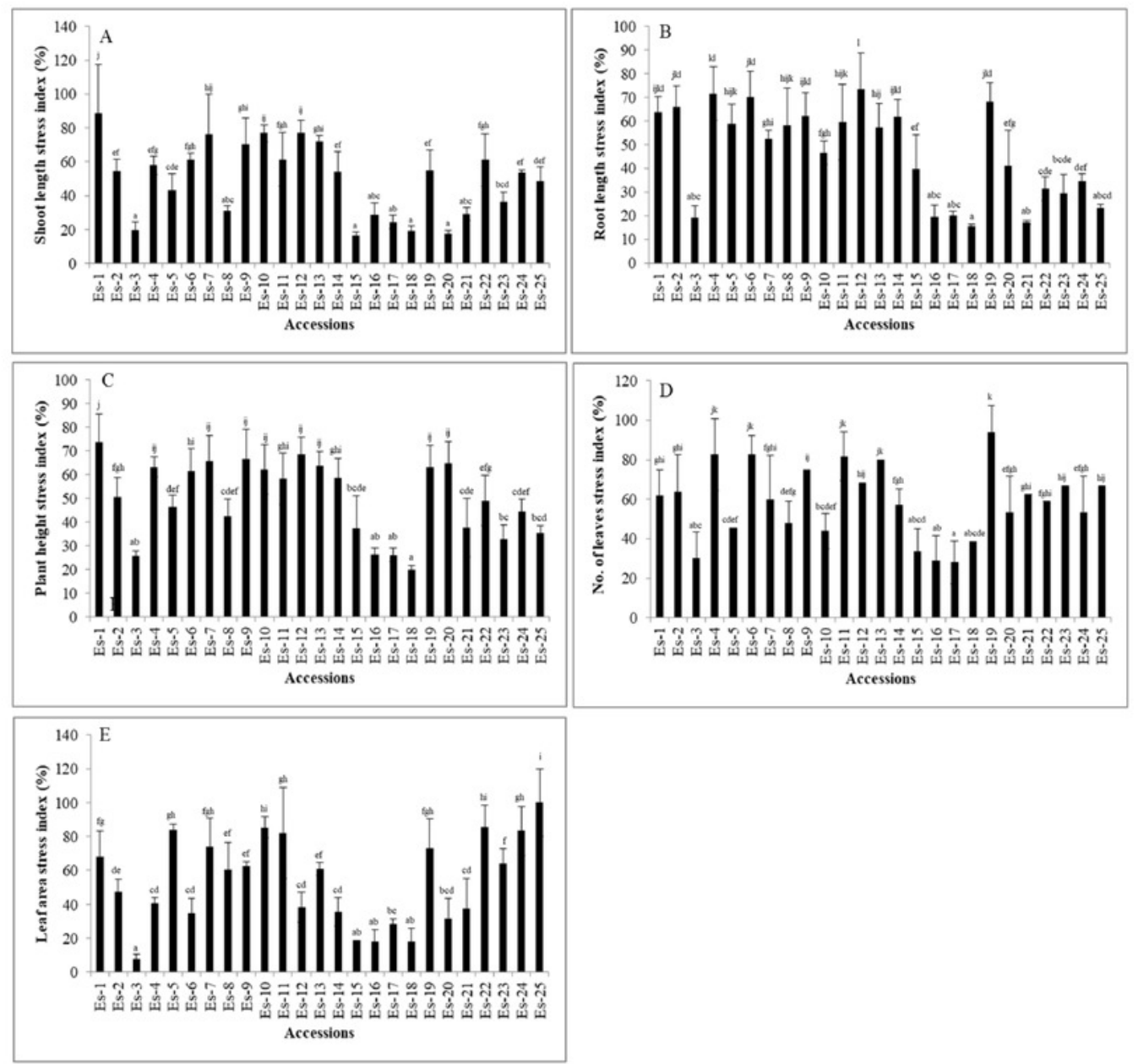


Figure 2

Effect of salt stress on biomass of E. sativa accessions (A) Fresh weight stress index (B) dry weight stress index.

Values are mean $( \pm S D)$ of three replicates.
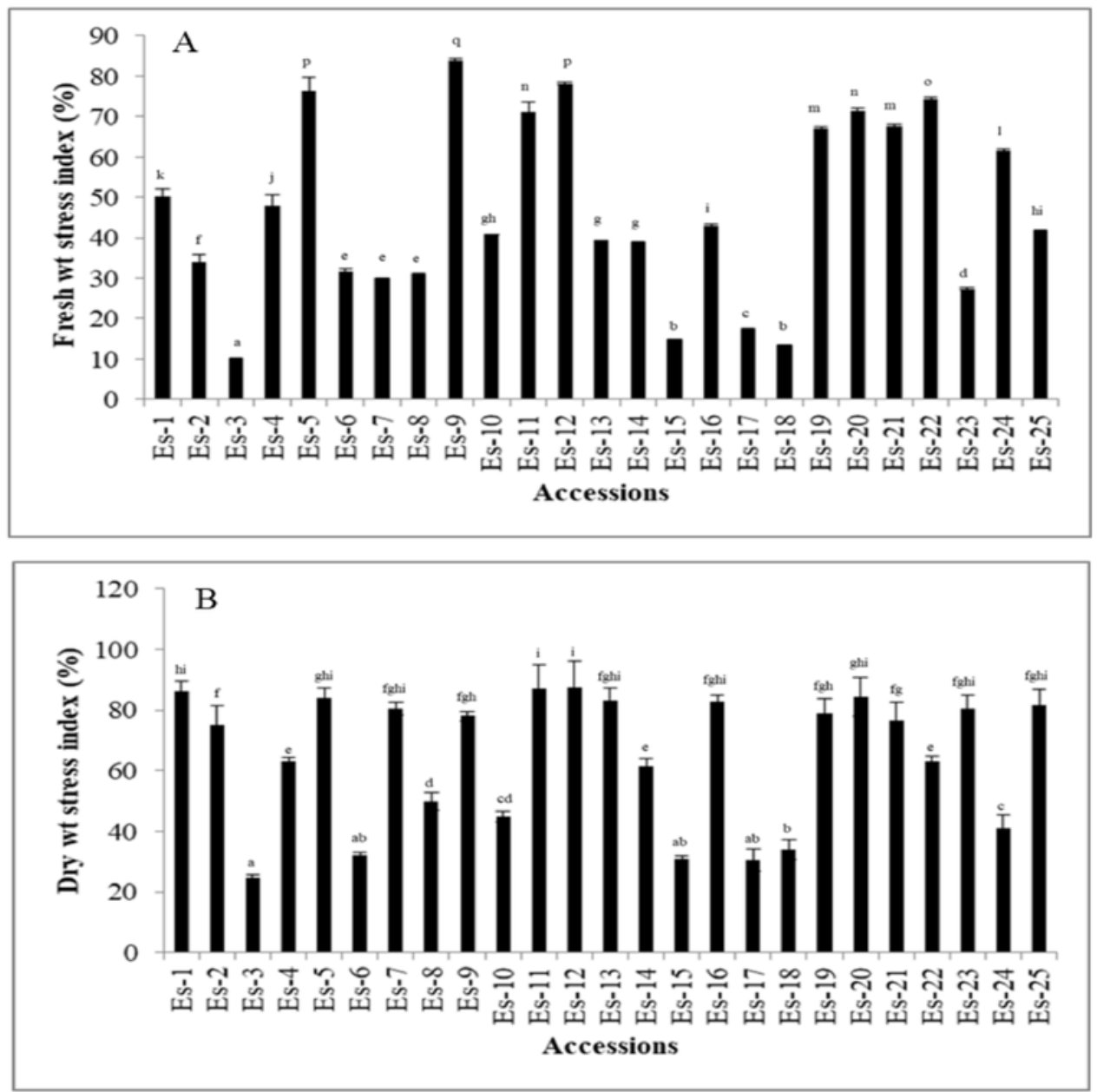


\section{Figure 3}

Electrolyte leakage in E. sativa accessions presented as ratio of treated/ control plants.

Data are mean $( \pm S D)$ of three replicates. Means with same letters are not significantly different tested by Duncan's multiple range test at $5 \%$ level.

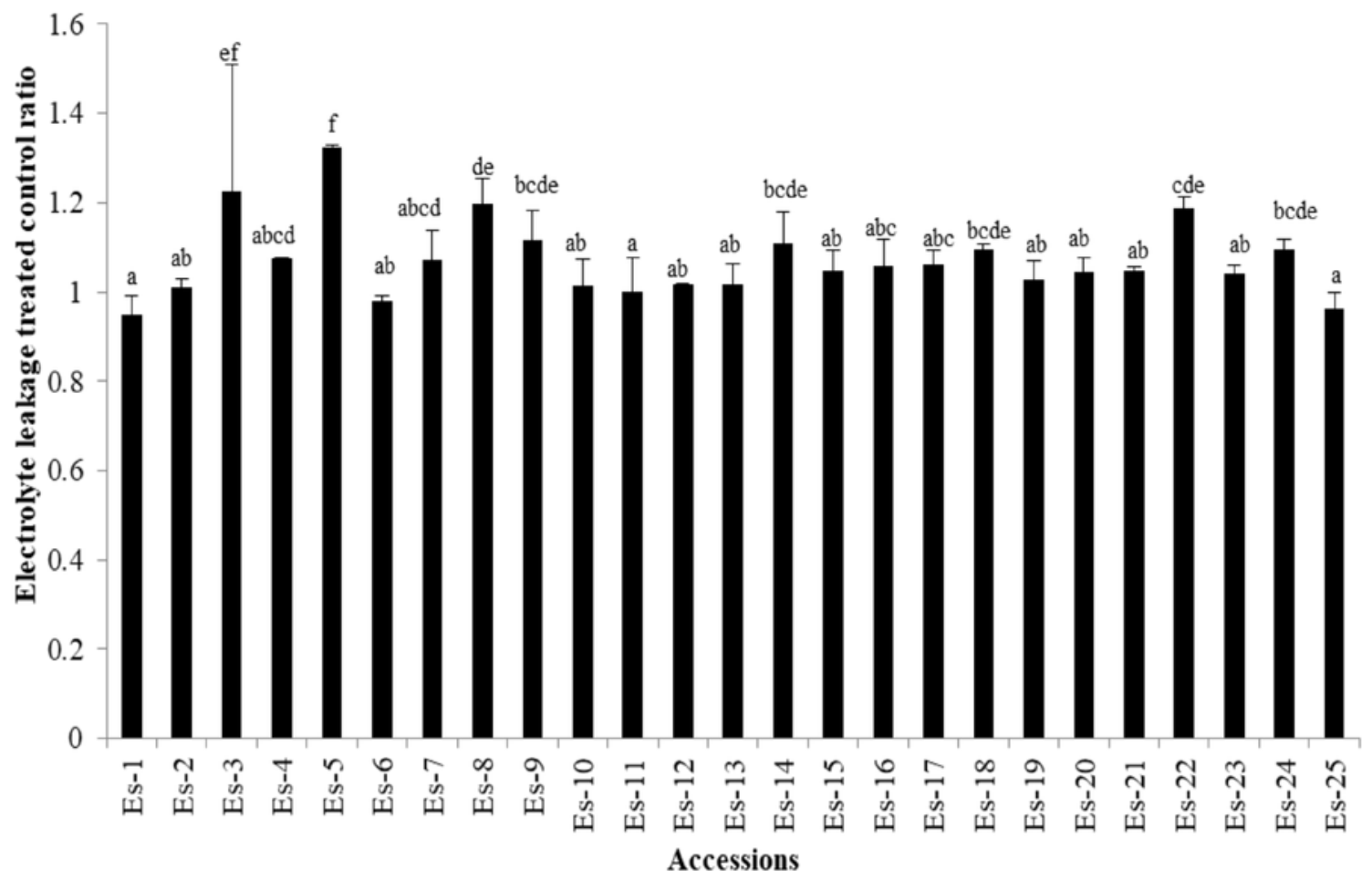


Figure 4

$\mathrm{K}^{+} / \mathrm{Na}^{+}$ratio stress index of Eruca sativa accessions.

Stress index was calculated as ratio of stressed to control and expressed as percentage. Data are mean $( \pm S D)$ of three replicates.

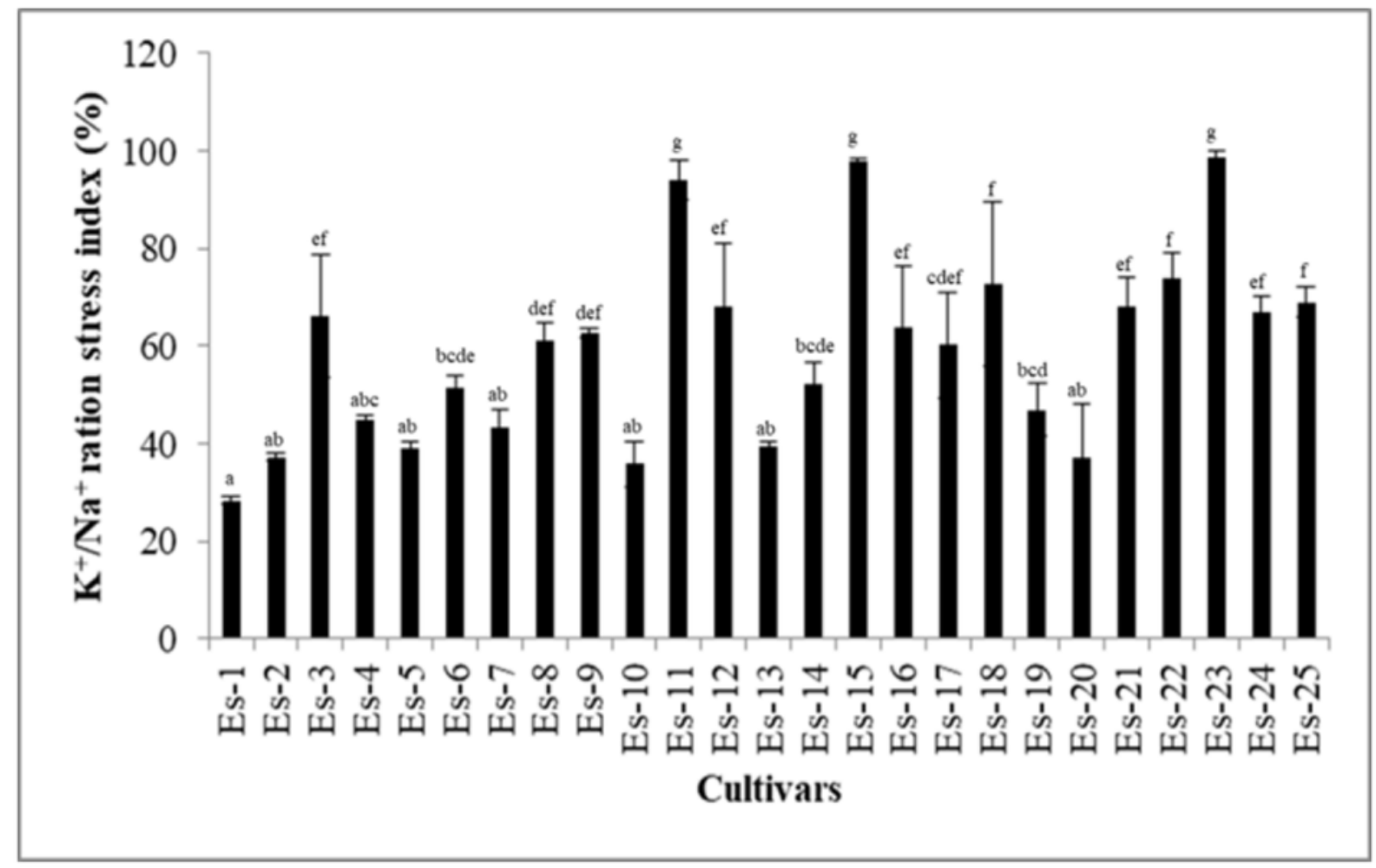


Figure 5

Principal component analysis (PCA). (A) biplot of Eruca sativa accessions based on the variation in 11 salt tolerance traits. (B) Eigenvalues of salt tolerance traits in PC1 and PC2.

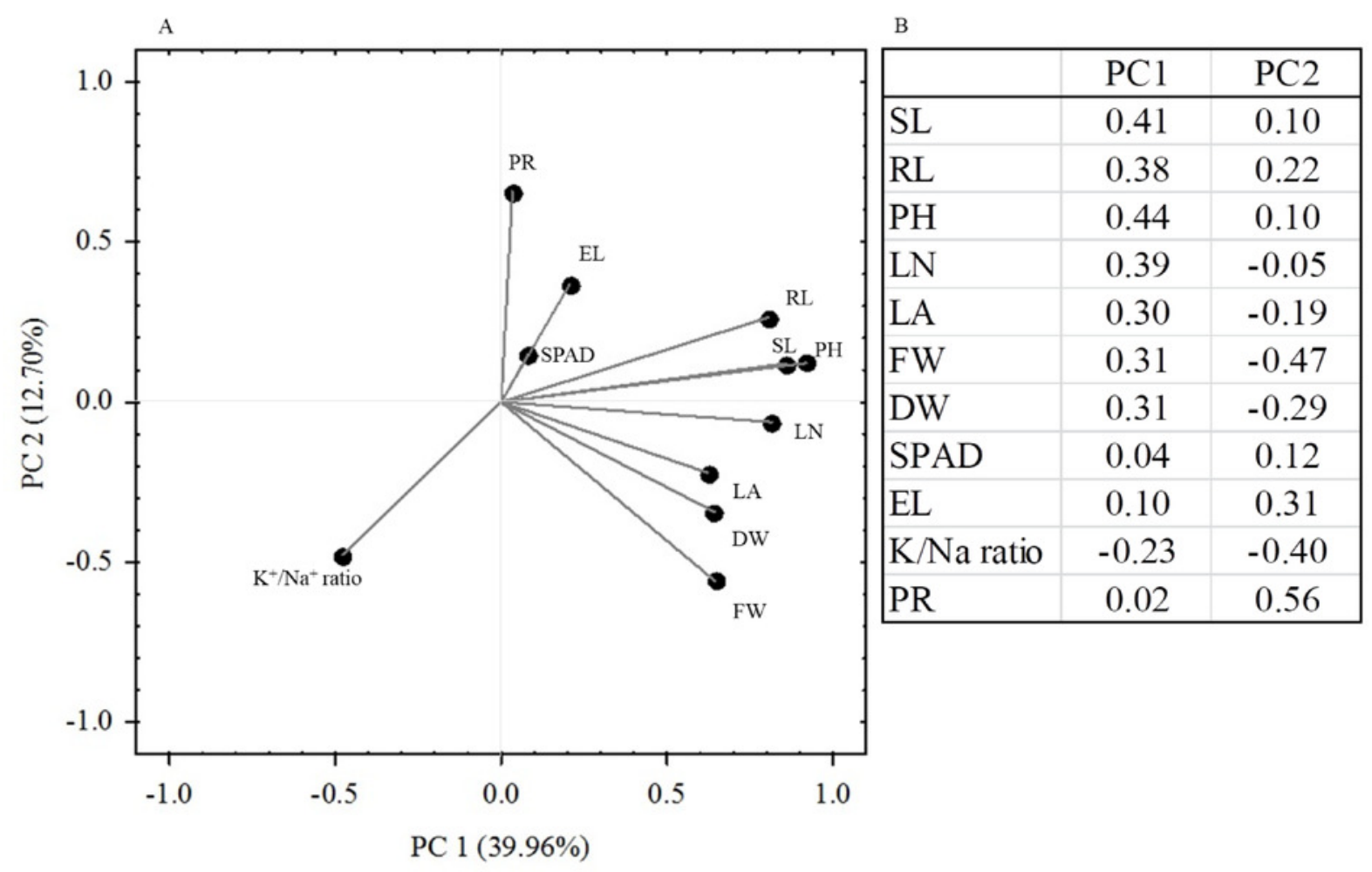




\section{Figure 6}

Pearson correlation matrix of the salt tolerance traits from 25 Eruca sativa accessions grown under $0 \mathrm{mM}$ and $150 \mathrm{mM} \mathrm{NaCl}$.

The color scale represents the nature of correlation. ${ }^{* * *},{ }^{* *}$ and $*$ show that correlation is significant at $0.001,0.01$ and 0.05 level, respectively.

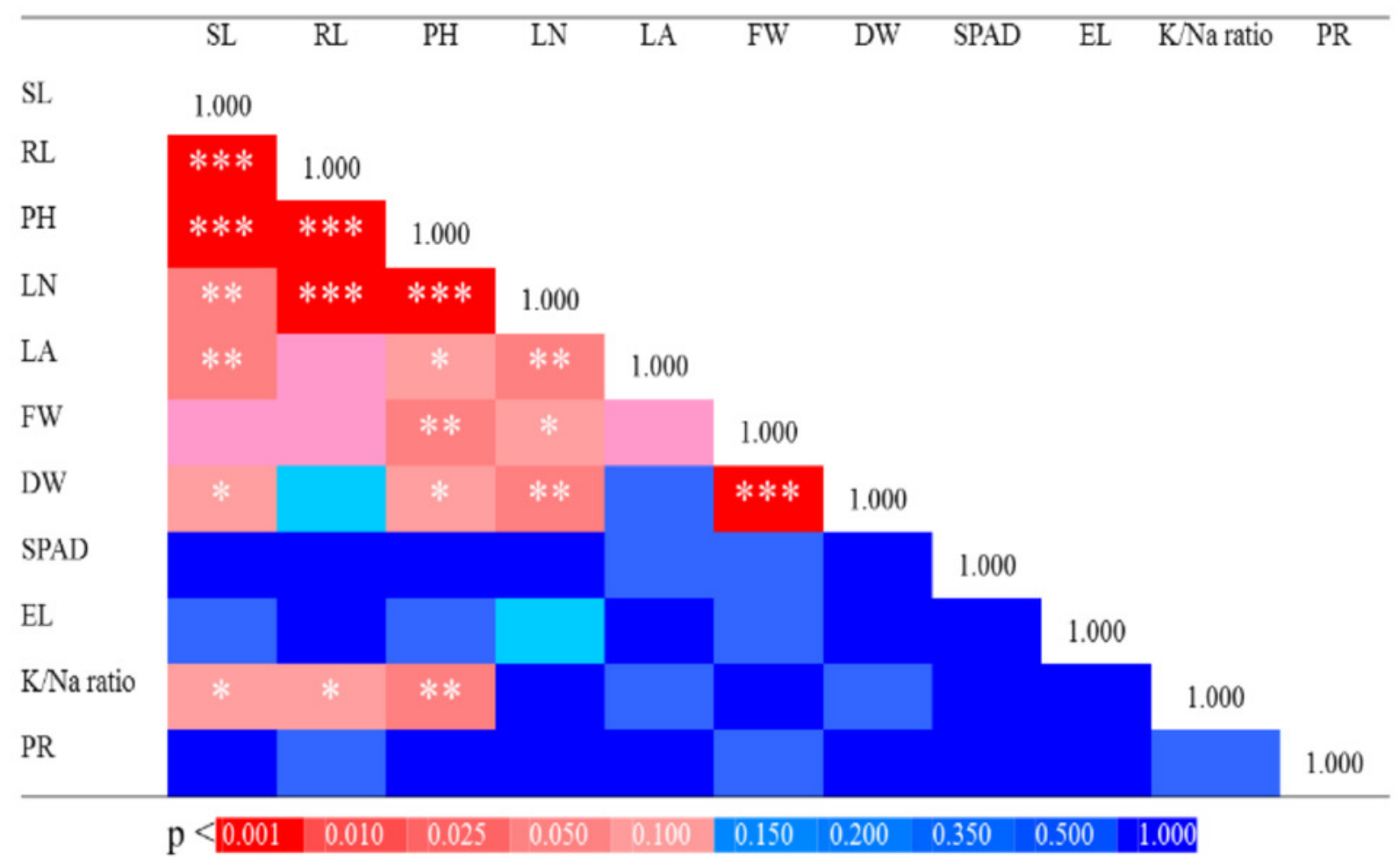


Figure 7

A dendrogram depicting the clustering of 25 Eruca sativa accessions based on Euclidean distance of salt stress tolerance-related traits.

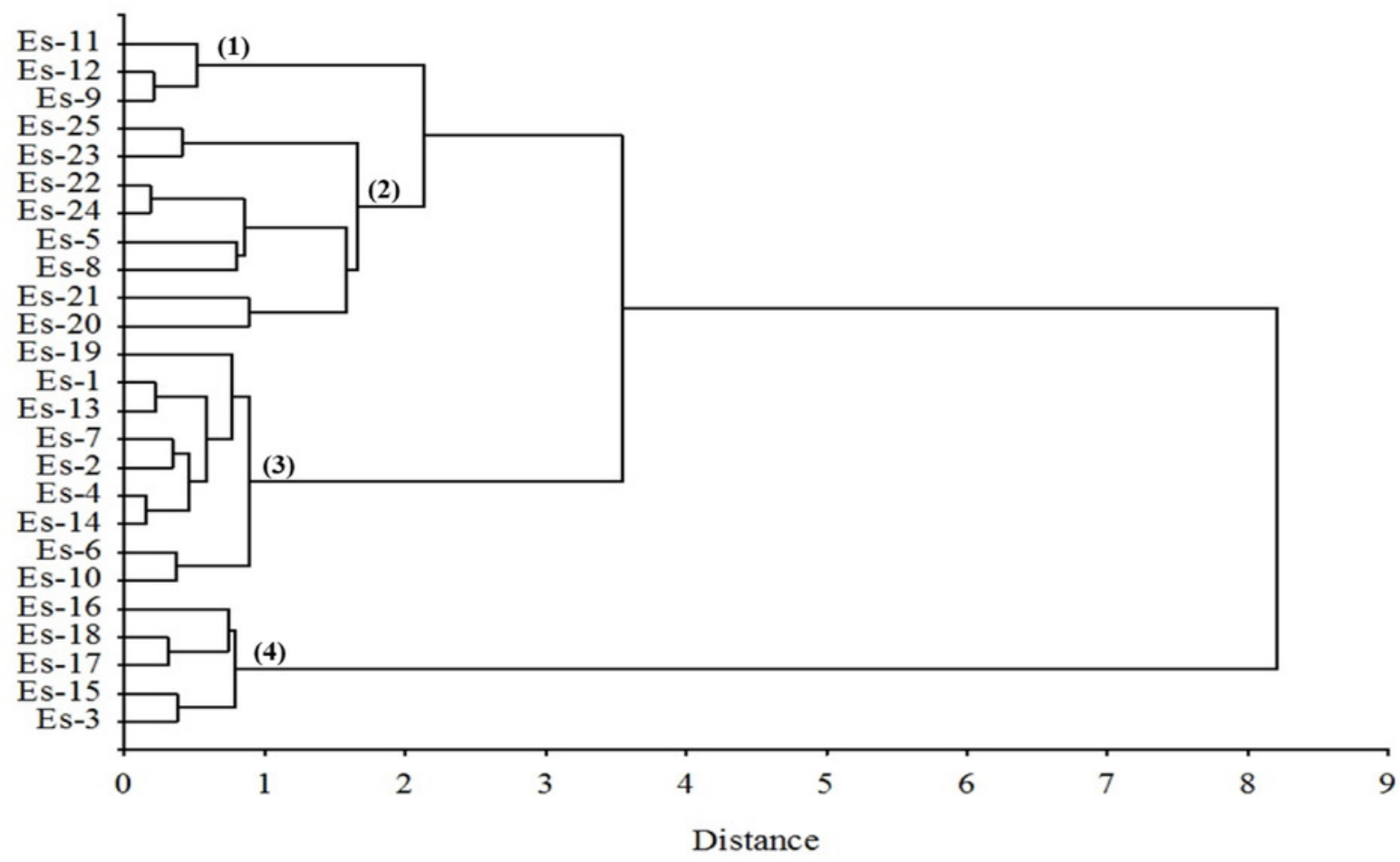




\section{Table $\mathbf{1}$ (on next page)}

Morphological traits determined in Eruca sativa accessions grown at $0 \mathrm{mM} \mathrm{NaCl}$ and 150 $\mathrm{mM} \mathrm{NaCl}$

SL - Shoot length, RL - Root length, PH - Plant height, LN - Leaf number, LA - Leaf area *Different letters show significant differences $(p<0.05)$ in each column (for same trait) and among treatments (Control vs $\mathrm{NaCl}$ ) 
Table 1 Morphological traits determined in E. sativa accessions grown at $0 \mathrm{mM} \mathrm{NaCl}$ and $150 \mathrm{mM} \mathrm{NaCl}$ 2

\begin{tabular}{|c|c|c|c|c|c|c|c|c|c|c|}
\hline \multirow[t]{2}{*}{ Accessions } & \multicolumn{2}{|c|}{ SL (inch) } & \multicolumn{2}{|c|}{ RL (inch) } & \multicolumn{2}{|c|}{ PH (inch) } & \multicolumn{2}{|c|}{ LN } & \multicolumn{2}{|c|}{ LA (inches') } \\
\hline & Control & $\mathrm{NaCl}$ & Control & $\mathrm{NaCl}$ & Control & $\mathrm{NaCl}$ & Control & $\mathrm{NaCl}$ & Control & $\mathrm{NaCl}$ \\
\hline Es-1 & $1.89^{\mathrm{Aijk}}$ & $1.69^{\text {Aghij }}$ & $2.40^{\text {Aopq }}$ & $1.54^{\text {Bghij }}$ & $4.15^{\text {Amnop }}$ & $3.08^{\mathrm{Bij}}$ & $4.2^{\mathrm{Aklmn}}$ & $2.6^{\text {Bcdef }}$ & $0.05^{\text {A,fghij }}$ & $0.03^{\text {A,bcdef }}$ \\
\hline Es-2 & $2.83^{\mathrm{Aq}}$ & $1.55^{\text {Bfghi }}$ & $1.93^{\mathrm{Aklm}}$ & $1.27^{\text {Bdefgh }}$ & 4.99Arst & $2.53^{\text {Befgh }}$ & 4. $4^{\text {Almno }}$ & $2.8^{\text {Bdefg }}$ & $0.08^{\mathrm{A}, \mathrm{op}}$ & $0.04^{\mathrm{B}, \mathrm{efgh}}$ \\
\hline Es-3 & $3.51^{\mathrm{Ar}}$ & $0.70^{\text {Bab }}$ & $2.35^{\text {Aop }}$ & $0.45^{\mathrm{Ba}}$ & 4.62 Aopqr & $1.18^{\mathrm{Ba}}$ & 4. $4^{\text {Almno }}$ & $1.33^{\mathrm{Ba}}$ & $0.16^{\mathrm{A}, \mathrm{r}}$ & $0.01^{\mathrm{B}, \mathrm{a}}$ \\
\hline Es-4 & $3.56^{\mathrm{Ar}}$ & 2.07 Bjklmn & $2.75^{\mathrm{Aqr}}$ & $1.98^{\mathrm{Blmn}}$ & $6.05^{\mathrm{Au}}$ & $3.83^{\mathrm{Bklm}}$ & 4. $6^{\text {Amnop }}$ & $3.8^{\mathrm{Bijk} l}$ & $0.09^{\mathrm{A}, \mathrm{q}}$ & $0.04^{\mathrm{B}, \text { efghi }}$ \\
\hline Es-5 & $2.48^{\text {Aop }}$ & $1.08^{\text {Bcde }}$ & $1.65^{\mathrm{Aijkl}}$ & $0.97^{\mathrm{Bbcd}}$ & $4.50^{\text {Anopqr }}$ & $2.08^{\text {Bbcde }}$ & 4.4 $4^{\text {Almno }}$ & $2^{\mathrm{Babc}}$ & $0.06^{\mathrm{A}, \mathrm{Imno}}$ & $0.06^{\mathrm{B}, \mathrm{ijk} 1}$ \\
\hline Es-6 & $2.01^{\mathrm{Ajkl}}$ & $1.23^{\text {Bdef }}$ & $1.48^{\text {Afghij }}$ & $1.04^{\mathrm{Bcd}}$ & $3.55^{\mathrm{Ajkl}}$ & $2.18^{\text {Bcdef }}$ & $4.6^{\text {Amnop }}$ & $3.8^{\mathrm{Bijk} l}$ & $0.08^{\mathrm{A}, \mathrm{op}}$ & $0.03^{\mathrm{B}, \mathrm{bcde}}$ \\
\hline Es-7 & $1.95^{\mathrm{Ajkl}}$ & $1.49^{\mathrm{Bggh}}$ & $2.19^{\text {Amno }}$ & $1.15^{\text {Bdef }}$ & $4.08^{\mathrm{Almn}}$ & $2.69^{\mathrm{Bfghi}}$ & $4^{\mathrm{Ajklm}}$ & $2.4^{\text {Bcde }}$ & $0.07^{\mathrm{A}, \mathrm{op}}$ & $0.06^{\mathrm{B}, \mathrm{j} k \mathrm{l}}$ \\
\hline Es-8 & $2.97^{\mathrm{Aq}}$ & $0.92^{\mathrm{Bbcd}}$ & $1.80^{\mathrm{Ajkl}}$ & $1.05^{\text {Bcde }}$ & $4.66^{\text {Apqrs }}$ & $1.97^{\mathrm{Bbcd}}$ & $5^{\text {Aopq }}$ & $2.4^{\text {Bcde }}$ & $0.07^{\mathrm{A}, \mathrm{mnop}}$ & $0.04^{\mathrm{B}, \text { efghi }}$ \\
\hline Es-9 & $2.42^{\text {Anop }}$ & $1.71^{\text {Bghij }}$ & $2.23^{\mathrm{Amno}}$ & $1.39^{\mathrm{Befghi}}$ & $4.64^{\text {Apqrs }}$ & $3.10^{\mathrm{Bij}}$ & $4^{\mathrm{Ajklm}}$ & $3^{\text {Befgh }}$ & $0.07^{\mathrm{A}, \mathrm{mnop}}$ & $0.04^{\mathrm{B}, \text { efghi }}$ \\
\hline Es-10 & $1.38^{\mathrm{Aefg}}$ & $1.06^{\text {Acde }}$ & $1.61^{\mathrm{Ahijk}}$ & $0.75^{\text {Babc }}$ & 3.04 Ahij & $1.89^{\mathrm{Bbcd}}$ & $5^{\text {Aopq }}$ & $2.2^{\mathrm{Bbcd}}$ & $0.08^{\mathrm{A}, \mathrm{p}}$ & $0.07^{\mathrm{A}, \mathrm{mnop}}$ \\
\hline Es-11 & 2.07Ajklmn & $1.27^{\text {Bdef }}$ & $1.89^{\mathrm{Aklm}}$ & $1.13^{\text {Bdef }}$ & $3.98^{\mathrm{Almn}}$ & $2.32^{\text {Bdefg }}$ & $4.4^{\mathrm{A}, \mathrm{lmno}}$ & $3.6^{\mathrm{Bhijk}}$ & $0.06^{\mathrm{A}, \mathrm{jjk} \mathrm{l}}$ & $0.04^{\text {A,fghij }}$ \\
\hline Es-12 & $1.78^{\text {Ahij }}$ & 1.37 Befg & $1.66^{\mathrm{Aijk} l}$ & $1.22^{\text {Bdefg }}$ & $3.44^{\mathrm{Ajk}}$ & $2.36^{\text {Bdefg }}$ & 4. $4^{\text {Almno }}$ & $3^{\text {Befgh }}$ & $0.06^{\mathrm{A}, \mathrm{jklm}}$ & $0.02^{\mathrm{B}, \mathrm{abcd}}$ \\
\hline Es-13 & $2.73^{\mathrm{Apq}}$ & $1.97^{\mathrm{Bjkl}}$ & $2.50^{\text {Aopq }}$ & $1.44^{\mathrm{Bfghi}}$ & $5.34^{\mathrm{At}}$ & $3.40^{\mathrm{Bjk}}$ & $5^{\text {Aopq }}$ & $4^{\mathrm{Bjklm}}$ & $0.07^{\mathrm{A}, \mathrm{nop}}$ & $0.04^{\mathrm{B}, \text { efghi }}$ \\
\hline Es-14 & $2.29^{\mathrm{Almno}}$ & $1.23^{\text {Bdef }}$ & $2.41^{\text {Aopq }}$ & $1.49^{\text {Bfghij }}$ & $4.78^{\text {Aqrs }}$ & $2.80^{\text {Bghi }}$ & $5.6^{\mathrm{Aq}}$ & $3.2^{\text {Bfghi }}$ & $0.08^{\mathrm{A}, \mathrm{pq}}$ & $0.03^{\mathrm{B}, \mathrm{bcde}}$ \\
\hline Es-15 & 2.07 Ajklmn & $0.35^{\mathrm{Ba}}$ & $2.42^{\text {Aopq }}$ & $0.97^{\mathrm{Bbcd}}$ & 4.38 Anopq & $1.64^{\mathrm{Bab}}$ & $4.75^{\text {Anop }}$ & $1.6^{\mathrm{Bab}}$ & $0.05^{\mathrm{A}, \mathrm{hijk}}$ & $0.01^{\mathrm{B}, \mathrm{a}}$ \\
\hline Es-16 & $2.42^{\text {Anop }}$ & $0.69^{\mathrm{Bab}}$ & $2.31^{\text {Ano }}$ & $0.45^{\mathrm{Ba}}$ & $4.64^{\mathrm{Apqrs}}$ & $1.22^{\mathrm{Ba}}$ & $4.6^{\text {Amnop }}$ & $1.33^{\mathrm{Ba}}$ & $0.07^{\mathrm{A}, \mathrm{mnop}}$ & $0.01^{\mathrm{B}, \mathrm{a}}$ \\
\hline Es-17 & $2.44^{\text {Anop }}$ & $0.60^{\mathrm{Bab}}$ & $2.23^{\mathrm{Amno}}$ & $0.45^{\mathrm{Ba}}$ & 4.69 Apqrs & $1.22^{\mathrm{Ba}}$ & $5^{\text {Aopq }}$ & $1.4^{\mathrm{Ba}}$ & $0.07^{\mathrm{A}, \mathrm{op}}$ & $0.02^{\mathrm{B}, \mathrm{abc}}$ \\
\hline Es-18 & $3.05^{\mathrm{Aq}}$ & $0.60^{\mathrm{Bab}}$ & $2.90^{\mathrm{Ar}}$ & $0.46^{\mathrm{Ba}}$ & $5.87^{\mathrm{Au}}$ & $1.16^{\mathrm{Ba}}$ & $5.2^{\mathrm{Apq}}$ & $2^{\text {Babc }}$ & $0.07^{\mathrm{A}, \mathrm{nop}}$ & $0.01^{\mathrm{B}, \mathrm{a}}$ \\
\hline Es-19 & $2.25^{\text {Aklmno }}$ & $1.23^{\text {Bdef }}$ & $2.18^{\mathrm{Amno}}$ & $1.49^{\text {Bfghij }}$ & $4.42^{\text {Anopq }}$ & $2.80^{\text {Bghi }}$ & $3.4^{\text {Aghij }}$ & $3.2^{\text {Afghi }}$ & $0.04^{\mathrm{A}, \text { efghi }}$ & $0.03^{\mathrm{B}, \mathrm{bcde}}$ \\
\hline Es-20 & $1.99^{\mathrm{Ajkl}}$ & $0.35^{\mathrm{Ba}}$ & 2.34 Aop & $0.97^{\mathrm{Bbcd}}$ & $4.33^{\text {Amnopq }}$ & $2.80^{\text {Bghi }}$ & $3^{\text {Aefgh }}$ & $1.6^{\mathrm{Bab}}$ & $0.03^{\mathrm{A}, \mathrm{defg}}$ & $0.01^{\mathrm{B}, \mathrm{a}}$ \\
\hline Es-21 & $1.99^{\mathrm{Ajkl}}$ & $0.60^{\mathrm{Bab}}$ & $2.68^{\text {Apqr }}$ & $0.46^{\mathrm{Ba}}$ & $4.71^{\mathrm{Apqrs}}$ & $1.78^{\mathrm{Bbc}}$ & $3.2^{\text {Afghi }}$ & $2^{\text {Babc }}$ & $0.04^{\mathrm{A}, \mathrm{efgh}}$ & $0.01^{\mathrm{B}, \mathrm{ab}}$ \\
\hline
\end{tabular}




\begin{tabular}{|c|c|c|c|c|c|c|c|c|c|c|}
\hline Es-22 & $1.73^{\text {Aghij }}$ & $1.22^{\text {Bdef }}$ & $2.47^{\text {Aopq }}$ & $0.78^{\mathrm{Babc}}$ & 4.33 Amnopq & $2.12^{\text {Bbcde }}$ & $3.4^{\text {Aghij }}$ & $2^{\text {Babc }}$ & $0.042^{\mathrm{A}, \text { efghi }}$ & $0.03^{\mathrm{A}, \mathrm{cdefg}}$ \\
\hline Es-23 & $1.40^{\text {Aefg }}$ & $0.63^{\mathrm{Bab}}$ & $1.8^{\mathrm{Ajkl}}$ & $0.53^{\mathrm{Ba}}$ & $3.53^{\mathrm{Ajkl}}$ & $1.16^{\mathrm{Ba}}$ & $3^{\text {Aefgh }}$ & $2^{\text {Babc }}$ & $0.05^{\mathrm{A}, \text { ghij }}$ & $0.03^{\mathrm{B}, \mathrm{bcdef}}$ \\
\hline Es-24 & 2.39Amnop & $0.75^{\mathrm{Bbc}}$ & $1.41^{\text {Afghi }}$ & $0.49^{\mathrm{Ba}}$ & $2.84^{\mathrm{Aghi}}$ & $1.26^{\mathrm{Ba}}$ & $3^{\text {Aefgh }}$ & $1.6^{\mathrm{Bab}}$ & $0.04^{\mathrm{A}, \mathrm{efgh}}$ & $0.03^{\mathrm{A}, \mathrm{bcdef}}$ \\
\hline Es-25 & $1.9^{\mathrm{Aijk}}$ & $1.17^{\text {Bdef }}$ & $2.74^{\mathrm{Aqr}}$ & $0.64^{\mathrm{Bab}}$ & $5.18^{\text {Ast }}$ & $1.83^{\mathrm{Bbcd}}$ & $3^{\text {Aefgh }}$ & $2^{\mathrm{Babc}}$ & $0.04^{\mathrm{A}, \text { efghi }}$ & $0.04^{\mathrm{A}, \text { efghi }}$ \\
\hline Mean & $2.30^{\mathrm{A}}$ & $1.10^{\mathrm{B}}$ & $2.17^{\mathrm{A}}$ & $0.98^{\mathrm{B}}$ & $4.43^{\mathrm{A}}$ & $2.18^{\mathrm{B}}$ & $4.22^{\mathrm{A}}$ & $2.43^{\mathrm{B}}$ & $0.07^{\mathrm{A}}$ & $0.03^{\mathrm{B}}$ \\
\hline S.D & 0.56 & 0.48 & 0.42 & 0.43 & 0.77 & 0.76 & 0.78 & 0.82 & 0.03 & 0.02 \\
\hline
\end{tabular}

3

$4 \quad \mathrm{SL}$ - Shoot length, RL - Root length, PH - Plant height, LN - Leaf number, LA - Leaf area

5 *Different lower case letters show significant differences $(p<0.05)$ in each column (for the same trait) while the upper case letters show significant differences $(p<0.05)$ among treatments (Control vs $\mathrm{NaCl}$ ). 


\section{Table 2 (on next page)}

Fresh weight (FW), Dry weight (DW), Relative water content (RWC) and Chlorophyll content (SPAD) in Eruca sativa accessions grown at $0 \mathrm{mM} \mathrm{NaCl}$ and $150 \mathrm{mM} \mathrm{NaCl}$

FW - fresh weight, DW - dry weight, RWC - relative water content, SPAD - Chlorophyll content *Different letters show significant differences $(p<0.05)$ in each column (for same trait) and among treatments (Control vs $\mathrm{NaCl}$ ) 
1 Table 2 Fresh weight (FW), Dry weight (DW), Relative water content (RWC) and Chlorophyll content (SPAD) in E. sativa 2 accessions grown at $0 \mathrm{mM} \mathrm{NaCl}$ and $150 \mathrm{mM} \mathrm{NaCl}$

\begin{tabular}{|c|c|c|c|c|c|c|c|c|}
\hline \multirow[t]{2}{*}{ Accessions } & \multicolumn{2}{|c|}{ FW (mg) } & \multicolumn{2}{|c|}{ DW (mg) } & \multicolumn{2}{|c|}{ RWC (\%) } & \multicolumn{2}{|c|}{ SPAD (CCI) } \\
\hline & Control & $\mathrm{NaCl}$ & Control & $\mathrm{NaCl}$ & Control & $\mathrm{NaCl}$ & Control & $\mathrm{NaCl}$ \\
\hline Es-1 & $343.1^{\mathrm{Av}}$ & $171.97^{\mathrm{Bmn}}$ & $20.93^{\mathrm{At}}$ & $18.05^{\mathrm{Br}}$ & $75.84^{\mathrm{Ab}}$ & $89.81^{\mathrm{Bcd}}$ & 16.88 Ahijklm & $13.65^{\text {Bdefg }}$ \\
\hline Es-2 & $173.13^{\mathrm{Amn}}$ & $58.83^{\mathrm{Bfg}}$ & $11.96^{\mathrm{Amn}}$ & $9.00^{\mathrm{Bk}}$ & $71.59^{\mathrm{Aa}}$ & $91.73^{\text {Bcdefghijkl }}$ & $21.16^{\text {Anopq }}$ & $15.2^{\text {Bdefghi }}$ \\
\hline Es-3 & $321.26^{\mathrm{Au}}$ & $32.76^{\mathrm{Bab}}$ & $15.93^{\mathrm{Aq}}$ & $3.93^{\mathrm{Befg}}$ & $76.89^{\mathrm{Ab}}$ & $89.22^{\mathrm{Bcd}}$ & $18.66^{\text {Ajklmno }}$ & $13.2^{\mathrm{Bdef}}$ \\
\hline Es-4 & $347.55^{\mathrm{Av}}$ & $165.95^{\mathrm{Bm}}$ & $19.72^{\mathrm{As}}$ & $12.45^{\text {Bno }}$ & $96.03^{\text {Amno }}$ & 96.34 Amno & 16.9 Ahijklm & $15.88^{\text {Afghijk }}$ \\
\hline Es-5 & $222.8^{\mathrm{Aq}}$ & $170.2^{\mathrm{Bmn}}$ & $12.93^{\text {Ao }}$ & $10.83^{\mathrm{B} 1}$ & 91.39Acdefghij & 94.63 Ahijklmn & $23.71^{\mathrm{Ars}}$ & $16.82^{\text {Bhijkl }}$ \\
\hline Es-6 & $754.8^{\mathrm{Az}}$ & $238.13^{\mathrm{Br}}$ & $32.53^{\mathrm{Au}}$ & $10.46^{\mathrm{Bl}}$ & $98.8^{\text {Ao }}$ & $96.00^{\text {Amno }}$ & 17.08 Ahijklm & $12.58^{\mathrm{Bcd}}$ \\
\hline Es-7 & $323.13^{\mathrm{Au}}$ & $96.47^{\mathrm{Bj}}$ & $10.6^{\mathrm{Al}}$ & $8.52^{\mathrm{Bk}}$ & $97.48^{\text {Ano }}$ & $96.00^{\text {Amno }}$ & $26.3^{\text {Ast }}$ & $31.31^{\mathrm{Bu}}$ \\
\hline Es-8 & $245.13^{\operatorname{Ars}}$ & $76.17^{\mathrm{Bi}}$ & $11.2^{\mathrm{Alm}}$ & $5.58^{\mathrm{Bh}}$ & $94.58^{\text {Aghijklmn }}$ & $92.02^{\text {Acdefghijkl }}$ & $9.8^{\mathrm{Aab}}$ & $6.93^{\mathrm{Aa}}$ \\
\hline Es-9 & $60.59^{\mathrm{Ag}}$ & $50.85^{\text {Bef }}$ & $3.48^{\text {Acdefg }}$ & $2.72^{\mathrm{Abcd}}$ & $91.55^{\text {Acdefghijk }}$ & $90.26^{\text {Acde }}$ & $27.4^{\mathrm{At}}$ & $31.31^{\mathrm{Bu}}$ \\
\hline Es-10 & $435.06^{\operatorname{Ax}}$ & $177.52^{\mathrm{Bn}}$ & $16^{\mathrm{Aq}}$ & $7.18^{\mathrm{Bij}}$ & $96.41^{\text {Amno }}$ & $94.72^{\text {Ahijklmn }}$ & $18.51^{\mathrm{Ajklmn}}$ & $13^{\text {Bdef }}$ \\
\hline Es-11 & $203.71^{\mathrm{Ap}}$ & $144.60^{\mathrm{Bl}}$ & $7.38^{\mathrm{Aj}}$ & $6.43^{\mathrm{Bi}}$ & 94.69Ahijklmn & 95.89Amno & 14.31 Adefgh & $9.35^{\mathrm{Bab}}$ \\
\hline Es-12 & $247.26^{\mathrm{As}}$ & $193.26^{\text {Bo }}$ & $10.6^{\mathrm{Al}}$ & $9.26^{\mathrm{Bk}}$ & $94.84^{\mathrm{Aijk} k \mathrm{mn}}$ & $95.2^{\text {Ajklmno }}$ & $15.66^{\text {Aefghij }}$ & $14.36^{\text {Adefgh }}$ \\
\hline Es-13 & 449.33 Аy & $176.71^{\mathrm{Bn}}$ & $11^{\mathrm{Al}}$ & $9.17^{\mathrm{Bk}}$ & $96.06^{\text {Amno }}$ & 94.59Aghijklmn & $15^{\text {Adefghi }}$ & $9.08^{\mathrm{Bab}}$ \\
\hline Es-14 & $426^{\mathrm{Aw}}$ & $165.55^{\mathrm{Bm}}$ & $14^{\mathrm{Ap}}$ & $8.61^{\mathrm{Bk}}$ & $97.35^{\text {Ano }}$ & $94.23^{\text {Afghijklmn }}$ & $24.88^{\text {Ast }}$ & $17.51^{\text {Bijklm }}$ \\
\hline Es-15 & $251.2^{\mathrm{As}}$ & $36.76^{\mathrm{Babc}}$ & $11.93^{\mathrm{Amn}}$ & $3.66^{\text {Bdefg }}$ & $95.45^{\text {Aklmno }}$ & $91.86^{\text {Acdefghijkl }}$ & $16.55^{\text {Aghijkl }}$ & $9.63^{\mathrm{Bab}}$ \\
\hline Es-16 & $77.00^{\mathrm{Ai}}$ & $33.09^{\mathrm{Babc}}$ & 3.67 Adefg & $3.03^{\text {Acde }}$ & $90.81^{\text {Acdefg }}$ & $89.22^{\text {Acd }}$ & $21.21^{\text {Anopq }}$ & $12.66^{\mathrm{Bcde}}$ \\
\hline Es-17 & $210.2^{\mathrm{Ap}}$ & $36.22^{\mathrm{Babc}}$ & $10.4^{\mathrm{Al}}$ & $3.18^{\mathrm{Bcde}}$ & $94.24^{\text {Afghijklmn }}$ & $91.31^{\text {Acdefghi }}$ & $15.18^{\text {Adefghi }}$ & $9.21^{\mathrm{Bab}}$ \\
\hline Es-18 & $307.93^{\mathrm{At}}$ & $40.94^{\mathrm{Bbcd}}$ & $8.66^{\mathrm{Ak}}$ & $2.94^{\mathrm{Bbcd}}$ & $96.56^{\text {Amno }}$ & $88.6^{\mathrm{Bc}}$ & $9.61^{\mathrm{Aab}}$ & $12.5^{\mathrm{Bcd}}$ \\
\hline Es-19 & $104.92^{\mathrm{Ak}}$ & $70.43^{\mathrm{Bhi}}$ & $5.33^{\mathrm{Ah}}$ & $4.20^{\mathrm{Bfg}}$ & 92.96 Adefghijklm & 94.27 Afghijklmn & $18.75^{\text {Aklmno }}$ & $16.51^{\text {Aghijkl }}$ \\
\hline Es-20 & $42.43^{\text {Acde }}$ & $30.3^{\mathrm{Ba}}$ & $3.2^{\text {Acde }}$ & $2.7^{\mathrm{Abc}}$ & $88.29^{A c}$ & $91.90^{\text {Acdefghijkl }}$ & $22.21 \mathrm{Aqr}$ & $14.66^{\text {Bdefghi }}$ \\
\hline
\end{tabular}




\begin{tabular}{|c|c|c|c|c|c|c|c|c|}
\hline Es-21 & $90.55^{\mathrm{Aj}}$ & $61.33^{\mathrm{Bg}}$ & $4.18^{\mathrm{Afg}}$ & $3.2^{\text {Bcde }}$ & 94.99 & $95.25^{\text {Ajklmno }}$ & $9.95^{\mathrm{Abc}}$ & $16.9^{\text {Bhijklm }}$ \\
\hline Es-22 & $48.40^{\text {Ade }}$ & $35.92^{\mathrm{Babc}}$ & $2.09^{\mathrm{Aab}}$ & $1.32^{\mathrm{Aa}}$ & 96.49Amno & $95.93^{\mathrm{Amno}}$ & $18.98^{\mathrm{Almno}}$ & $8.01^{\mathrm{Bab}}$ \\
\hline Es-23 & $138.11^{\mathrm{Al}}$ & $37.79^{\mathrm{Babc}}$ & $4.16^{\mathrm{Afg}}$ & $3.35^{\text {Acdef }}$ & 94.44 Aghijklmn & $91.63^{\text {Acdefghijkl }}$ & $21.5^{\text {Apqr }}$ & $8.83^{\mathrm{Bab}}$ \\
\hline Es-24 & $107.8^{\mathrm{Ak}}$ & $66.40^{\mathrm{Bgh}}$ & $7.66^{\mathrm{Aj}}$ & $3.14^{\text {Bcde }}$ & $90.97^{\text {Acdefgh }}$ & $89.62^{\mathrm{Acd}}$ & $14.21^{\text {Adefgh }}$ & $9.41^{\mathrm{Bab}}$ \\
\hline Es- 25 & $95.33^{\mathrm{Aj}}$ & $39.93^{\mathrm{Bbcd}}$ & $5.28^{\mathrm{Ah}}$ & $4.31^{\mathrm{Bg}}$ & 93.99Aefghijklmn & $90.57^{\text {Acdef }}$ & $19.83^{\text {Amnop }}$ & $12.95^{\text {Bdef }}$ \\
\hline Mean & $241.07^{\mathrm{A}}$ & $96.33^{\mathrm{B}}$ & $10.60^{\mathrm{A}}$ & $6.29^{\mathrm{B}}$ & $92.11^{\mathrm{A}}$ & $92.83^{\mathrm{A}}$ & $18.17^{\mathrm{A}}$ & $14.06^{\mathrm{B}}$ \\
\hline S.D. & 164.93 & 66.23 & 6.88 & 3.99 & 7.01 & 2.58 & 4.79 & 6.02 \\
\hline
\end{tabular}

$4 \quad *$ Different lower case letters show significant differences $(p<0.05)$ in each column (for the same trait) while the upper case letters show significant differences $5(p<0.05)$ among treatments (Control vs $\mathrm{NaCl})$. 


\section{Table 3(on next page)}

Gas exchange parameters of Eruca sativa accessions grown at $0 \mathrm{mM} \mathrm{NaCl}$ and $150 \mathrm{mM}$ $\mathrm{NaCl}$

*Different letters show significant differences $(p<0.05)$ in each column (for same trait) and among treatments (Control vs $\mathrm{NaCl}$ ) 
Table 3 Gas exchange parameters of E. sativa accessions grown at $0 \mathrm{mM} \mathrm{NaCl}$ and $150 \mathrm{mM} \mathrm{NaCl}$

\begin{tabular}{|c|c|c|c|c|c|c|c|c|}
\hline \multirow[t]{2}{*}{ Accessions } & \multicolumn{2}{|c|}{$\begin{array}{l}\text { Photosynthesis rate } \\
\left(\mu \mathrm{molm}^{-2} \mathrm{~s}^{-1}\right)\end{array}$} & \multicolumn{2}{|c|}{$\begin{array}{l}\text { Intercellular } \mathrm{CO}_{2} \\
\mu_{\mathrm{mol} \mathrm{mol}}^{-1}\end{array}$} & \multicolumn{2}{|c|}{$\begin{array}{l}\text { Transpiration rate } \\
\left(\mathrm{mmol} \mathrm{m}^{-2} \mathrm{~s}^{-1}\right)\end{array}$} & \multicolumn{2}{|c|}{$\begin{array}{l}\text { Stomatal conductance } \\
\left(\mathrm{mmolm}^{-2} \mathrm{~s}^{-1}\right)\end{array}$} \\
\hline & Control & $\mathrm{NaCl}$ & Control & $\mathrm{NaCl}$ & Control & $\mathrm{NaCl}$ & Control & $\mathrm{NaCl}$ \\
\hline Es-1 & $12.5^{\mathrm{Agh}}$ & $4.24^{\text {Bbcde }}$ & $286^{\text {Abcdefghij }}$ & $245.5^{\text {Aabcd }}$ & $3.16^{\mathrm{Agh}}$ & $1.64^{\text {Bbcde }}$ & $0.22^{\text {Ade }}$ & $0.08^{\mathrm{Bab}}$ \\
\hline Es-2 & $2.74^{\text {Aabcde }}$ & $1.78^{\mathrm{Aabc}}$ & $271.5^{\text {Aabcdefgh }}$ & $288.5^{\text {Abcdefghij }}$ & $0.91^{\text {Aabcd }}$ & $1.12^{\text {Aabcd }}$ & $0.04^{\mathrm{Aab}}$ & $0.04^{\mathrm{Aab}}$ \\
\hline Es-3 & $17^{\mathrm{Ai}}$ & $1.34^{\mathrm{Ba}}$ & $290.5^{\text {Abcdefghij }}$ & $258^{\text {Aabcde }}$ & $4.18^{\mathrm{Ah}}$ & $0.56^{\mathrm{Bab}}$ & $0.31^{\text {Af }}$ & $0.02^{\mathrm{Ba}}$ \\
\hline Es-4 & $13^{\mathrm{Agh}}$ & $3.4^{\text {Babcde }}$ & $279^{\text {Aabcdefgh }}$ & $273^{\text {Aabcdefgh }}$ & $3.55^{\mathrm{Agh}}$ & $1.38^{\text {Babcde }}$ & $0.21^{\text {Ade }}$ & $0.06^{\mathrm{Bab}}$ \\
\hline Es-5 & $9.10^{\mathrm{Af}}$ & $2.62^{\text {Babcde }}$ & $280^{\text {Aabcdefgh }}$ & $312.5^{\text {Adefghijk }}$ & $3.45^{\mathrm{Agh}}$ & $1.94^{\text {Bdef }}$ & $0.2^{\text {Ade }}$ & $0.05^{\mathrm{Bab}}$ \\
\hline Es-6 & $4.96^{\text {Ade }}$ & $1.22^{\mathrm{Ba}}$ & $281.5^{\text {Aabcdefghi }}$ & $315^{\text {Aefghijk }}$ & $3.88^{\mathrm{Ah}}$ & $1.03^{\text {Babcd }}$ & $0.2^{\text {Ade }}$ & $0.03^{\mathrm{Bab}}$ \\
\hline Es-8 & $2.85^{\text {Aabcde }}$ & $1.53^{\mathrm{Aab}}$ & $300.5^{\text {Acdefghijk }}$ & $333^{\text {Aghijk }}$ & $1.57^{\text {Abcde }}$ & $1.3^{\text {Aabcd }}$ & $0.07^{\mathrm{Aab}}$ & $0.05^{\mathrm{Aab}}$ \\
\hline Es-9 & $14.01^{\mathrm{Agh}}$ & $2.46^{\text {Babcde }}$ & $255^{\text {Aabcde }}$ & $251^{\text {Aabcde }}$ & $3.46^{\mathrm{Agh}}$ & $0.68^{\mathrm{Babcd}}$ & $0.23^{\text {Ade }}$ & $0.03^{\mathrm{Bab}}$ \\
\hline Es-10 & $8.8^{\mathrm{Af}}$ & $2.51^{\text {Babcde }}$ & $281.5^{\text {Aabcdefghi }}$ & $258.5^{\text {Aabcde }}$ & $3.48^{\mathrm{Agh}}$ & $1.24^{\mathrm{Babcd}}$ & $0.17^{\text {Acde }}$ & $0.06^{\mathrm{Bab}}$ \\
\hline Es-11 & $3.28^{\text {Aabcde }}$ & $1.16^{\mathrm{Aa}}$ & $290^{\text {Abcdefghij }}$ & 329Afghijk & $1.65^{\mathrm{Abcde}}$ & $0.63^{\text {Aabc }}$ & $0.07^{\mathrm{Aab}}$ & $0.03^{\mathrm{Aa}}$ \\
\hline Es-12 & $9.06^{\mathrm{Af}}$ & $3.31^{\text {Babcde }}$ & $255.5^{\text {Aabcde }}$ & $281.5^{\text {Aabcdefghi }}$ & $3.14^{\mathrm{Agh}}$ & $1.85^{\text {Bcdef }}$ & $0.15^{\text {Acd }}$ & $0.07^{\mathrm{Bab}}$ \\
\hline Es-13 & $14.8^{\mathrm{Ahi}}$ & $2.5^{\text {Babcde }}$ & $294^{\text {Acdefghijk }}$ & $223.5^{\mathrm{Bab}}$ & $3.64^{\mathrm{Agh}}$ & $0.68^{\text {Babcd }}$ & $0.2^{\text {Ade }}$ & $0.03^{\mathrm{Ba}}$ \\
\hline Es-14 & $8.83^{\mathrm{Af}}$ & $3.18^{\text {Babcde }}$ & $294.5^{\text {Acdefghijk }}$ & $274.5^{\text {Aabcdefgh }}$ & $2.59^{\mathrm{Aefg}}$ & $1.25^{\mathrm{Babcd}}$ & $0.2^{\text {Ade }}$ & $0.05^{\mathrm{Bab}}$ \\
\hline Es-15 & $5.16^{\mathrm{Ae}}$ & $1.37^{\mathrm{Ba}}$ & $315.5^{\text {Aefghijk }}$ & $215.5^{\mathrm{Ba}}$ & $1.93^{\mathrm{Adef}}$ & $0.26^{\mathrm{Ba}}$ & $0.11^{\mathrm{Abc}}$ & $0.01^{\mathrm{Ba}}$ \\
\hline Es-17 & $1.14^{\mathrm{Aa}}$ & $0.76^{\mathrm{Aa}}$ & $340^{\text {Ahijk }}$ & $315^{\text {Aefghijk }}$ & $1.07^{\text {Aabcd }}$ & $0.37^{\mathrm{Aab}}$ & $0.05^{\mathrm{Aab}}$ & $0.03^{\mathrm{Aa}}$ \\
\hline Es-18 & $2.84^{\text {Aabcde }}$ & $1.42^{\mathrm{Aa}}$ & $306^{\text {Acdefghijk }}$ & $349.5^{\mathrm{Aijk}}$ & 1.40 Aabcde & $1 \mathrm{~A}^{\mathrm{abcd}}$ & $0.07^{\mathrm{Aab}}$ & $0.03^{\mathrm{Aa}}$ \\
\hline Es-19 & $2.16^{\mathrm{Aabc}}$ & $1.62^{\mathrm{Aab}}$ & 287Abcdefghij & $293^{\text {Acdefghij }}$ & $3.64^{\mathrm{Agh}}$ & $0.57^{\mathrm{Babc}}$ & $0.2^{\text {Ade }}$ & $0.04^{\mathrm{Bab}}$ \\
\hline Es-20 & $12.7^{\mathrm{Agh}}$ & $1.75^{\mathrm{Babc}}$ & $238^{\text {Aabc }}$ & $215.5^{\mathrm{Aa}}$ & $3^{\text {Afgh }}$ & $0.46^{\mathrm{Bab}}$ & $0.16^{\mathrm{Acd}}$ & $0.02^{\mathrm{Ba}}$ \\
\hline Es-21 & $12.18^{\mathrm{Ag}}$ & $2.57^{\text {Babcde }}$ & $274^{\text {Aabcdefgh }}$ & $265.5^{\text {Aabcdefg }}$ & $4.14^{\mathrm{Ah}}$ & $1.23^{\mathrm{Babcd}}$ & $0.25^{\mathrm{Ae}}$ & $0.06^{\mathrm{Bab}}$ \\
\hline Es-22 & $4.26^{\mathrm{Abcde}}$ & $1.24^{\mathrm{Ba}}$ & 259Aabcde & $275^{\text {Aabcdefgh }}$ & $1.33^{\mathrm{Aabcd}}$ & $0.83^{\text {Aabcd }}$ & $0.06^{\mathrm{Aab}}$ & $0.03^{\mathrm{Aab}}$ \\
\hline Es-23 & $5.04^{\mathrm{Ae}}$ & $0.77^{\mathrm{Ba}}$ & $246^{\text {Aabcd }}$ & $264^{\text {Aabcdef }}$ & $1.56^{\mathrm{Abcde}}$ & $0.66^{\text {Aabcd }}$ & $0.06^{\mathrm{Aab}}$ & $0.03^{\mathrm{Aa}}$ \\
\hline
\end{tabular}




\begin{tabular}{lllllllll} 
Es-24 & $4.47^{\text {Acde }}$ & $0.9^{\mathrm{Ba}}$ & $276.5^{\text {Aabcdefgh }}$ & $361^{\mathrm{Bk}}$ & $1.52^{\text {Aabcde }}$ & $0.61^{\text {Aabc }}$ & $0.06^{\text {Aab }}$ & $0.03^{\text {Aa }}$ \\
Es-25 & $2.27^{\text {Aabcd }}$ & $0.71^{\text {Aa }}$ & $266^{\text {Aabcdefg }}$ & $350.5^{\text {Bjk }}$ & $0.99^{\text {Aabcd }}$ & $0.38^{\text {Aab }}$ & $0.06^{\text {Aab }}$ & $0.03^{\text {Aab }}$ \\
\hline Mean & $7.5^{\mathrm{A}}$ & $1.91^{\mathrm{B}}$ & $281.20^{\mathrm{A}}$ & $284.70^{\mathrm{A}}$ & $2.57^{\mathrm{A}}$ & $0.94^{\mathrm{B}}$ & $0.14^{\mathrm{A}}$ & $0.04^{\mathrm{B}}$ \\
S.D & 4.69 & 0.97 & 22.90 & 42.57 & 1.13 & 0.48 & 0.08 & 0.02 \\
\hline
\end{tabular}

3 *Different lower case letters show significant differences $(p<0.05)$ in each column (for the same trait) while the upper case letters show significant differences $4 \quad(p<0.05)$ among treatments (Control vs $\mathrm{NaCl})$. 


\section{Table 4 (on next page)}

Determination of mineral elements in Eruca sativa accessions grown at $0 \mathrm{mM} \mathrm{NaCl}$ and $150 \mathrm{mM} \mathrm{NaCl}$

*Different letters show significant differences $(p<0.05)$ in each column (for same trait) and among treatments (Control vs $\mathrm{NaCl}$ ) 
1 Table 4 Determination of mineral elements in E. sativa accessions grown at $0 \mathrm{mM} \mathrm{NaCl}$ and $150 \mathrm{mM} \mathrm{NaCl}$

\begin{tabular}{|c|c|c|c|c|c|c|c|c|c|c|}
\hline \multirow{2}{*}{$\begin{array}{l}\text { Accession } \\
\text { S }\end{array}$} & \multicolumn{2}{|c|}{$\mathrm{Na}^{+}\left(\mathrm{mg} \mathrm{g}^{-1} \mathrm{DW}\right)$} & \multicolumn{2}{|c|}{$K^{+}\left(\mathbf{m g ~ g}^{-1} \mathbf{D W}\right)$} & \multicolumn{2}{|c|}{$\mathrm{Ca}^{2+}\left(\mathrm{mg} \mathrm{g}^{-1} \mathrm{DW}\right)$} & \multicolumn{2}{|c|}{$\mathrm{Mg}^{2+}\left(\mathrm{mg} \mathrm{g}^{-1} \mathrm{DW}\right)$} & \multicolumn{2}{|c|}{$\mathbf{K}^{+} / \mathbf{N a}^{+}$ratio } \\
\hline & Control & $\mathrm{NaCl}$ & Control & $\mathrm{NaCl}$ & Control & $\mathrm{NaCl}$ & Control & $\mathrm{NaCl}$ & Control & $\mathrm{NaCl}$ \\
\hline Es-1 & $4.6^{\mathrm{Aa}}$ & $21.5^{\text {Bklmnopq }}$ & $8.72^{\mathrm{Aab}}$ & $11.55^{\text {Abcdef }}$ & $4.02^{\text {Aabcde }}$ & $3.51^{\text {Aabcd }}$ & $2.74^{\text {Aabc }}$ & $2.53^{\mathrm{Aab}}$ & $1.89^{\mathrm{Au}}$ & $0.53^{\mathrm{Babc}}$ \\
\hline Es-2 & $6.035^{\mathrm{Aab}}$ & $23.86^{\text {Bopqrs }}$ & $8.81^{\mathrm{Aabc}}$ & $12.98^{\text {Bdefghi }}$ & 4.28 Aabcde & $3.73^{\text {Aabcd }}$ & 3.49Aabcdefg & $2.82^{\text {Aabcd }}$ & $1.46^{\mathrm{At}}$ & $0.54^{\mathrm{Babc}}$ \\
\hline \multirow[t]{2}{*}{ Es-3 } & $7.43^{\text {Aabcd }}$ & 16.99 Bhijklm & $9.59^{\text {Aabcd }}$ & $14.46^{\text {Befghijk }}$ & 5.69 Adefghi & $5.73^{\text {Adefghi }}$ & 3.78 Aabcdefg & $3.55^{\text {Aabcdefgh }}$ & $1.29^{\text {Aqrst }}$ & $0.86^{\text {Bdefghijkl }}$ \\
\hline & & & & & & & hi & & & $\mathrm{m}$ \\
\hline \multirow[t]{2}{*}{ Es-4 } & 7.07Aabc & $22.16^{\text {Bmnopq }}$ & $6.95^{\mathrm{Aa}}$ & 9.74 Aabcd & $2.68^{\mathrm{Aa}}$ & $2.92^{\mathrm{Aab}}$ & $5.10^{\text {Acdefghij }}$ & 3.88 Aabcdefghi & $0.98^{\text {Aijklmnop }}$ & $0.43^{\mathrm{Ba}}$ \\
\hline & & $\mathrm{r}$ & & & & & $\mathrm{k}$ & & & \\
\hline \multirow[t]{2}{*}{ Es-5 } & 9.97 Aabcdef & $27.53^{\mathrm{Brst}}$ & $12.06^{\text {Abcdefg }}$ & $13.02^{\text {Adefghi }}$ & $5.29^{\text {Abcdefg }}$ & $4.01^{\text {Aabcde }}$ & $7.24^{\mathrm{Aklm}}$ & 4.89 Abcdefghij & $1.20^{\text {Aopqrst }}$ & $0.47^{\mathrm{Bab}}$ \\
\hline & & & & & $\mathrm{h}$ & & & $\mathrm{k}$ & & \\
\hline \multirow[t]{2}{*}{ Es-6 } & $10.67^{\text {Abcdef }}$ & $25.01^{\text {Bpqrs }}$ & $12.20^{\text {Abcdefg }}$ & 14.71 Aefghijk & $3.095^{\mathrm{Aabc}}$ & $2.87^{\mathrm{Aab}}$ & $5.18^{\text {Acdefghij }}$ & $3.51^{\text {Aabcdefg }}$ & $1.14^{\text {Amnopqrs }}$ & $0.58^{\text {Babcde }}$ \\
\hline & $\mathrm{g}$ & & & 1 & & & $\mathrm{k}$ & & & \\
\hline \multirow[t]{2}{*}{ Es-7 } & $13.15^{\text {Adefghi }}$ & $30.72^{\mathrm{Btu}}$ & $16.65^{\mathrm{Aijk} l m n}$ & 16.97Ajklmno & $3.98^{\text {Aabcde }}$ & $3.04^{\mathrm{Aabc}}$ & 3.69Aabcdefg & $2.71^{\mathrm{Aabc}}$ & $1.27^{\text {Apqrst }}$ & $0.55^{\text {Babcd }}$ \\
\hline & & & & & & & $\mathrm{h}$ & & & \\
\hline \multirow[t]{2}{*}{ Es-8 } & 15.59Aefghij & $31.9^{\text {Btu }}$ & 17.59Aklmno & $21.96^{\text {Bpqrs }}$ & 7.78Ahijklm & $6.38^{\text {Aefghij }}$ & 9.49Anop & $8.85^{\text {Amno }}$ & $1.12^{\text {Almnopqr }}$ & $0.69^{\text {Babcdefgh }}$ \\
\hline & & & & & & & & & & $\mathrm{i}$ \\
\hline Es-9 & $16.21^{\text {Aghijkl }}$ & $31.85^{\mathrm{Btu}}$ & $33.4^{\mathrm{Av}}$ & $41.30^{\mathrm{Bw}}$ & 8.99Aklmn & $13.46^{\mathrm{Bq}}$ & $8.11^{\mathrm{Almn}}$ & $5.33^{\text {Bdefghijk }}$ & $2.06^{\mathrm{Au}}$ & $1.29^{\mathrm{Bqrst}}$ \\
\hline Es-10 & 9.81 Aabcde & $35.98^{\mathrm{Buv}}$ & $12.51^{\text {Acdefgh }}$ & 16.71 Bijklmn & 4.68 Aabcdef & $8.51^{\mathrm{Bjklm}}$ & 3.44 Aabcdef & $2.90^{\text {Aabcd }}$ & $1.29^{\mathrm{Aqrst}}$ & $0.46^{\mathrm{Bab}}$ \\
\hline \multirow[t]{2}{*}{ Es-11 } & $15.51^{\text {Aefghij }}$ & $18.54^{\mathrm{Aijklmn}}$ & $18.38^{\text {Almnop }}$ & $20.71^{\text {Aopqr }}$ & $9.86^{\text {Amnop }}$ & $11^{\text {Anop }}$ & 4.42 Aabcdefg & $4.25^{\text {Aabcdefghi }}$ & $1.18^{\text {Anopqrst }}$ & $1.11^{\text {Almnopqr }}$ \\
\hline & & o & & & & & hij & & & \\
\hline \multirow[t]{2}{*}{ Es-12 } & $16.83^{\text {Ahijklm }}$ & $20.31^{\mathrm{Ajklmn}}$ & $14.54^{\text {Aefghij }}$ & 11.98 Abcdefg & 3.98 Aabcde & $7.14^{\text {Bfghijk }}$ & $6.07^{\text {Ahijkl }}$ & $5.50^{\text {Aefghijk }}$ & $0.86^{\text {Aefghijkl }}$ & $0.59^{\text {Aabcde }}$ \\
\hline & & op & $\mathrm{kl}$ & & & & & & $\mathrm{m}$ & \\
\hline
\end{tabular}




\begin{tabular}{|c|c|c|c|c|c|c|c|c|c|c|}
\hline Es-13 & $\begin{array}{l}10.55^{\text {Abcdef }} \\
\mathrm{g}\end{array}$ & $27.91^{\mathrm{Bst}}$ & $\begin{array}{l}\text { 15.09Afghijk1 } \\
\mathrm{m}\end{array}$ & $\begin{array}{l}\text { 15.77 Aghijkl } \\
\mathrm{mn}\end{array}$ & 5.47 Acdefgh & 7.99Bijklm & $\begin{array}{l}4.50^{\text {Aabcdefg }} \\
\text { hij }\end{array}$ & $3.15^{\text {Aabcde }}$ & $1.43^{\mathrm{Ast}}$ & $0.56^{\text {Babcde }}$ \\
\hline Es-14 & $12.84^{\text {Adefghi }}$ & $35.57^{\mathrm{Buv}}$ & $13.03^{\text {Adefghi }}$ & $18.91^{\text {Bmnopq }}$ & $4.43^{\text {Aabcde }}$ & $10.12^{\text {Bmnop }}$ & $\begin{array}{l}4.19^{\text {Aabcdefg }} \\
\text { hi }\end{array}$ & $3.73^{\text {Aabcdefghi }}$ & $\begin{array}{l}1.01^{\text {Aklmnopq }} \\
\mathrm{r}\end{array}$ & $0.53^{\text {Babc }}$ \\
\hline Es-15 & $15.76^{\text {Afghijk }}$ & $\begin{array}{l}21.62^{\text {Blmnop }} \\
q\end{array}$ & $12.65^{\text {Adefgh }}$ & $17.02^{\text {Bjklmno }}$ & $4.13^{\text {Aabcde }}$ & 5.79Adefghi & $\begin{array}{l}4.34^{\text {Aabcdefg }} \\
\text { hij }\end{array}$ & $3.22^{\text {Aabcde }}$ & $\begin{array}{l}0.80^{\text {Acdefghij }} \\
\mathrm{k}\end{array}$ & $\begin{array}{l}0.79^{\text {Acdefghij }} \\
\mathrm{k}\end{array}$ \\
\hline Es-16 & $\begin{array}{l}10.68^{\text {Abcdef }} \\
\mathrm{g}\end{array}$ & $22.97^{\text {Bnopqrs }}$ & $13.63^{\text {Aefghij }}$ & $19.24^{\mathrm{Bnopqr}}$ & 5.48 Acdefgh & $12.09^{\mathrm{Bpq}}$ & $\begin{array}{l}3.87^{\text {Aabcdefg }} \\
\text { hi }\end{array}$ & $2.78^{\mathrm{Aabc}}$ & $1.30^{\text {Arst }}$ & $\begin{array}{l}0.83^{\text {Bcdefghij }} \\
\mathrm{kl}\end{array}$ \\
\hline Es-17 & $\begin{array}{l}17.87^{\text {Ahijklm }} \\
\mathrm{n}\end{array}$ & $47.04^{\mathrm{Bxy}}$ & $\begin{array}{l}17.13^{\mathrm{Ajklmn}} \\
\mathrm{o}\end{array}$ & $26.58^{\mathrm{Bu}}$ & $7.26^{\mathrm{Aghijkl}}$ & $23.16^{\mathrm{Br}}$ & $6.25^{\mathrm{Aijkl}}$ & $\begin{array}{l}4.61^{\text {Aabcdefghi }} \\
j\end{array}$ & $0.96^{\text {Ahijklmno }}$ & $0.58^{\text {Babcde }}$ \\
\hline Es-18 & $24.72^{\text {Apqrs }}$ & $38.14^{\mathrm{Bvw}}$ & $22.81^{\text {Arst }}$ & $25.36^{\text {Astu }}$ & $\begin{array}{l}4.88^{\text {Aabcdef }} \\
\mathrm{g}\end{array}$ & $13.56^{\mathrm{Bq}}$ & $\begin{array}{l}5.05^{\text {Abcdefghi }} \\
\text { jk }\end{array}$ & $3.76^{\text {Aabcdefghi }}$ & $\begin{array}{l}0.92^{\text {Aghijklmn }} \\
\text { o }\end{array}$ & $0.67^{\text {Aabcdefgh }}$ \\
\hline Es-19 & $\begin{array}{l}12.51^{\text {Acdefg }} \\
\mathrm{h}\end{array}$ & $32.4^{\text {Btu }}$ & $18.36^{\text {Almnop }}$ & $22.16^{\mathrm{Bqrs}}$ & $2.60^{\mathrm{Aa}}$ & $6.94^{\mathrm{Bfghijk}}$ & 5.99Aghijkl & $3.78^{\text {Aabcdefghi }}$ & $1.47^{\mathrm{At}}$ & $\begin{array}{l}0.69^{\text {Babcdefgh }} \\
\text { i }\end{array}$ \\
\hline Es-20 & $13.82^{\text {Aefghi }}$ & $48.11^{\mathrm{By}}$ & $26.50^{\mathrm{Au}}$ & $33.35^{\mathrm{Bv}}$ & $13.46^{\mathrm{Aq}}$ & $21.62^{\mathrm{Br}}$ & $6.83^{\mathrm{Ajklm}}$ & $\begin{array}{l}4.77^{\text {Aabcdefghi }} \\
\mathrm{jk}\end{array}$ & $1.91^{\mathrm{Au}}$ & $\begin{array}{l}0.71^{\text {Babcedfgh }} \\
\text { ij }\end{array}$ \\
\hline Es-21 & $24.9^{\text {Apqrs }}$ & $44.65^{\text {Bxy }}$ & $24.81^{\text {Astu }}$ & $30.41^{\mathrm{Bv}}$ & $8.28^{\mathrm{Ajklm}}$ & $12.02^{\mathrm{Bpq}}$ & $10.53^{\text {Aop }}$ & $5.82^{\text {Bfghijkl }}$ & $\begin{array}{l}1.00^{\mathrm{Ajklmnop}} \\
\mathrm{q}\end{array}$ & $\begin{array}{l}0.68^{\text {Babcdefgh }} \\
\text { i }\end{array}$ \\
\hline Es-22 & $16.87^{\text {Ahijklm }}$ & $28.21^{\mathrm{Bst}}$ & $12.70^{\text {Adefgh }}$ & $\begin{array}{l}15.63^{\text {Aghijkl }} \\
\mathrm{mn}\end{array}$ & $9.59^{\text {Almno }}$ & $13.33^{\text {Bq }}$ & $5.55^{\text {Aefghijk }}$ & $\begin{array}{l}4.65^{\text {Aabcdefghi }} \\
j\end{array}$ & $\begin{array}{l}0.75^{\text {Abcdefghi }} \\
\text { jk }\end{array}$ & $0.56^{\text {Aabcde }}$ \\
\hline Es-23 & $\begin{array}{l}17.41^{\text {Ahijklm }} \\
\mathrm{n}\end{array}$ & $26.70^{\text {Bqrst }}$ & $10.94^{\text {Abcde }}$ & $\begin{array}{l}16.50^{\text {Bhijklm }} \\
\mathrm{n}\end{array}$ & $8.63^{\mathrm{Ajklmn}}$ & $9.90^{\text {Amnop }}$ & $3.17^{\text {Aabcde }}$ & $2.27^{\mathrm{Aa}}$ & $0.63^{\text {Aabcdefg }}$ & $0.62^{\text {Aabcdef }}$ \\
\hline Es-24 & $13.83^{\text {Aefghi }}$ & $28.32^{\mathrm{Bst}}$ & $\begin{array}{l}13.90^{\text {Aefghij }} \\
\mathrm{k}\end{array}$ & $19.10^{\text {Bnopq }}$ & 6.39Aefghij & 7.4 $4^{\text {Ahijkl }}$ & $14.25^{\mathrm{Aq}}$ & $5.6^{\text {Befghijk }}$ & $\begin{array}{l}1.00^{\text {Ajklmnop }} \\
q\end{array}$ & $0.67^{\text {Babcdefgh }}$ \\
\hline
\end{tabular}




\begin{tabular}{|c|c|c|c|c|c|c|c|c|c|c|}
\hline Es-25 & $15.45^{\text {Aefghij }}$ & $41.97^{\mathrm{Bwx}}$ & $\begin{array}{l}13.94^{\text {Aefghij }} \\
\text { k }\end{array}$ & $26.22^{\text {Btu }}$ & 5.81 Adefghi & $11.76^{\text {Bopq }}$ & $11.35^{\mathrm{Ap}}$ & 9.95 Anop & $\begin{array}{l}0.90^{\text {Afghijklm }} \\
\mathrm{n}\end{array}$ & $0.62^{\text {Aabcdefg }}$ \\
\hline Mean & $13.52^{\mathrm{A}}$ & $29.55^{\mathrm{B}}$ & $15.61^{\mathrm{A}}$ & $19.44^{\mathrm{B}}$ & $6.03^{\mathrm{A}}$ & $9.08^{\mathrm{B}}$ & $5.35^{\mathrm{A}}$ & $4.06^{\mathrm{B}}$ & $1.22^{\mathrm{A}}$ & $0.67^{\mathrm{B}}$ \\
\hline S.D & 5.01 & 8.80 & 6.09 & 7.46 & 2.63 & 5.34 & 2.86 & 1.84 & 0.36 & 0.20 \\
\hline
\end{tabular}

3 *Different lower case letters show significant differences $(p<0.05)$ in each column (for the same trait) while the upper case letters show significant differences $4 \quad(p<0.05)$ among treatments (Control vs $\mathrm{NaCl})$. 


\section{Table 5 (on next page)}

Membership function values (MFV) calculated based on morpho-physiological traits in Eruca sativa accessions

*HT: Highly tolerant, T: Tolerant, MT: Moderately tolerant, S: Sensitive, HS: Highly sensitive 
Table 5 Membership function values (MFV) calculated based on morpho-physiological traits in E. sativa accessions 2

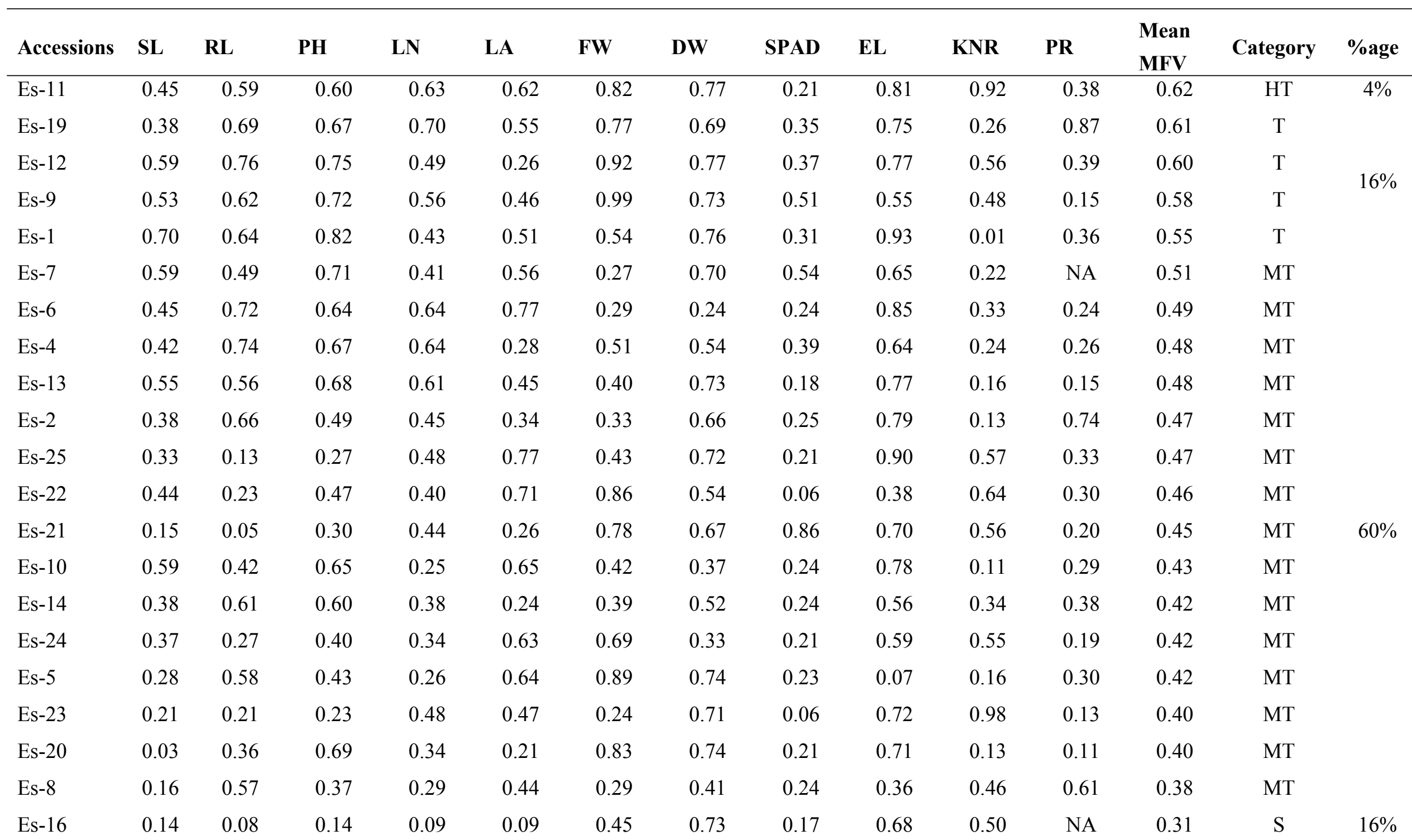




\begin{tabular}{|c|c|c|c|c|c|c|c|c|c|c|c|c|c|c|}
\hline Es-15 & 0.03 & 0.34 & 0.30 & 0.14 & 0.10 & 0.07 & 0.23 & 0.16 & 0.70 & 0.97 & 0.27 & 0.30 & $\mathrm{~S}$ & \\
\hline Es-18 & 0.05 & 0.03 & 0.04 & 0.19 & 0.06 & 0.05 & 0.26 & 0.61 & 0.59 & 0.62 & 0.56 & 0.28 & $\mathrm{~S}$ & \\
\hline Es-17 & 0.10 & 0.09 & 0.14 & 0.08 & 0.18 & 0.10 & 0.23 & 0.18 & 0.67 & 0.45 & 0.77 & 0.27 & $\mathrm{~S}$ & \\
\hline Es-3 & 0.06 & 0.08 & 0.13 & 0.11 & 0.01 & 0.01 & 0.17 & 0.24 & 0.61 & 0.53 & 0.03 & 0.18 & HS & $4 \%$ \\
\hline
\end{tabular}

